\title{
Slovesnost ob 20-letnici Pleteršnikovega muzeja v Pišecah in okrogla miza Slovensko slovaropisje (Pišece, 2. 10. 2014)
}

V zavetju Orliškega hribovja, ob izviru Gabernice ter med vinskimi griči in v senci dišečih marelic je preživljal svoje otroštvo in svoja zrela leta profesor in slovaropisec Maks Pleteršnik. Ob 20. obletnici obnove Pleteršnikove domačije in vzpostavitve muzeja v njej je Društvo za varovanje materinega jezika, naravne in kulturne dediščine »Maksa Pleteršnika« Pišece pripravilo prireditev, na kateri so sodelovali člani Društva Pleteršnikova domačija s Pleteršnikovimi pevci, šolsko mladino in ustvarjalci kulture v Pišecah. Prireditev je potekala 2. oktobra 2014 na Pleteršnikovi domačiji in v Kulturni dvorani pri šoli v centru Pišec, in sicer po naslednjem programu:

9.00-10.00: Prihod gostov in šolske mladine (prigrizek in ogled Pleteršnikovega muzeja oz. domačije)

10.00: Pozdrav domačinov, občine in predsednika Strokovnega odbora Maksa Pleteršnika, dr. Marka Jesenška

10.15-12.00: Kviz osnovnošolcev o življenju in delu slovarnika Maksa Pleteršnika z vmesnim kulturno - zabavnim programom (Gimnazija Brežice in OŠ Pišece)

12.15-14.30: Okrogla miza z naslovom Slovensko slovaropisje

15.00-16.00: Slavnostna akademija (kulturni program v dvorani v izvedbi Pleteršnikovih pevcev

(KD Orlica Pišece in OŠ Maksa Pleteršnika; slavnostni govornik dr. Marko Jesenšek, dekan FF Univerze Maribor).

\section{SLAVNOSTNI GOVOR NA PROSLAVI OB 20-LETNICI PleteršniKovega MUZEJA V PIŠECAH}

Pozdravljam Vas v imenu mariborske Filozofske fakultete, ki si tako kot pišeška šola nenehno prizadeva za širjenje mednarodnega sodelovanja. V globalnem evropskem in svetovnem prostoru si ob dobrem sodelovanju prizadevamo predvsem za promocijo in uveljavljanje slovenskega jezika v univerzitetnem, znanstvenem in raziskovalnem prostoru. Slovenski jezik je sicer eden izmed uradnih jezikov Evropske zveze, vendar pa je v praksi vse prepogosto in nekritično (tudi in predvsem $v$ znanosti) nadomeščan $z$ globalno angleščino. 
Če smo v preteklosti znali preseči ponesrečeno sintagmo o lepem, pravilnem knjižnem jeziku in grdih, nepravilnih narečjih in če se zavedamo, da jezik kot sporazumevalno sredstvo ne more biti lep ali grd, pravilen ali nepravilen (govorimo lahko le funkcijsko popolnem in usposobljenem jeziku, oz. o takem, ki to še ni ali ni več), potem moramo prej ali slej tudi spoznati, da angleščina ni in ne sme postati univerzalni učni jezik in edini jezik znanosti. Razvoj jezikov nam kaže, da so izumrli tudi kralji med jeziki (npr. stara grščina in latinščina), ko so postali funkcijsko okrnjeni in nepopolni. Izgubljanje ene funkcijske zvrsti, tj. znanstvenega in strokovnega jezika, je lahko začetek konca nekega jezika.

Znanost in kultura sta najvišji vrednoti, ki ju zmorejo ceniti le narodi, ki dajo kaj nase. Poglavitna opora teh vrednot je nacionalni jezik in če ga ne bomo znali uporabljati, ceniti in spoštovati, bomo izgubili svoj narodni značaj, identiteto in kulturne pridobitve, s katerimi smo se Slovenci npr. tudi s Pleteršnikovim slovarjem prepoznavno zasidrali v sodobno evropsko zavest. Boj za individualnost slovenskega jezika je bil v preteklosti predvsem boj za individualnost slovenstva, za samostojnost in neodvisnost - ideja slovenskega naroda je bila neposredno povezana in odvisna od vprašanja slovenskega jezika, njegove rabe in funkcijskozvrstne razširjenosti oz. popolnosti.

Izrinjanje nacionalnih jezikov iz univerzitetnih predavalnic, osnovnih in srednjih šol ter nadomeščanje nacionalnega učnega in znanstvenega jezika $z$ nadomestnim angleškim bi lahko pomenilo začetek konca takega nacionalnega jezika - humanistična inteligenca se zato še s posebno skrbjo zavzema za pravice in potrebo slovenskega (ter drugih nacionalnih) jezikov v izobraževanju, stroki, znanosti in raziskavah.

$\mathrm{V}$ teh okvirih vidim tudi izzive, ki jih Pleteršnikova pozitivna dediščina postavlja pred nas - pojmovanje jezika kot pojava, ki si sam ohranja in razvija sposobnost za ubesedovanje potreb dane jezikovne skupnosti. Pleteršnikovo slovaropisno delo je prižgalo zeleno luč za jezikovno odprtost, jezikovno kulturo in jezikovno predanost, ustavlja pa naj negativno jezikovno asimilacijo, ki se v imenu globalizacije, modnosti in eksibicionizma poskuša uveljaviti $v$ znanosti in raziskovanju, politiki ter posameznih strokah, tudi v šolstvu. Vse, kar velja za knjižni jezik, se v enaki in še večji meri kaže tudi v narečjih in narečni razčlenjenosti vsakega jezika, zato so Pleteršnikove Pišece poklicane za novi razmislek o vlogi in položaju nacionalnih jezikov ter narečij v globalnem svetu. Kraj je prepoznaven po skrbi za slovenski jezik in kulturo, za kar ima zaslugo srečno naključje, da se je 3. decembra 1840 leta v tej vasici rodil znameniti slovenski slovaropisec Maks Pleteršnik in da so se domačini odločili graditi svojo identiteto in prepoznavnost tudi na njegovem delu in skrbi za slovenski jezik. Danes tako praznujemo dvajsetletnico obnove Pleteršnikove domačije, tj. pomembnega vseslovenskega dogodka, ki je Pišece odprl v svet. Gospa Marjanca Ogorevc, nekdanji ravnatelj Martin Dušič in nekdanji piššši župnik Franc Ornik so ob sodelovanju domačinov kraju vdihnili Pleteršnikovo dušo in Pleteršnikov duh ter ga naredili prepoznavnega v Sloveniji in Evropski zvezi. Pišece so pod okriljem Društva za varovanje maternega jezika in kulturne dediščine Maksa Pleteršnika ter Strokovnega odbora Maksa Pleteršnika postale pomembno središče za raziskovanje 
slovaropisnih vprašanj. Začelo se je z okroglo mizo o vprašanjih slovenskega slovaropisja, ki jo je pripravil takratni predsednik SD Slovenije dr. France Novak, simpozijsko delo je v Pišecah organiziral akademik dr. Jože Toporišič ob vsestranski pomoči tajnice Strokovnega odbora dr. Irene Orel, njunega dela pa mi ni bilo težko nadaljevati in tako so Pleteršnikovi dnevi, vsakoletno srečanje slovenskih slovaropiscev, prerasli v odmevno mednarodno srečanje leksikografov s celega sveta. Pišece so gostile vse najpomembnejše slovenske jezikoslovce, ki skrbijo za nadaljevanje in ohranjanje Pleteršnikove dediščine, v zadnjih letih pa so na mednarodnih simpozijih sodelovali tudi ugledni leksikografi iz Avstrije, Italije, Madžarske, Poljske, Češke, Danske, Nemčije in Južnoafriške republike. Šest obsežnih monografij kaže, da so Pišece postale pomembno slovaropisno središče, spoznanja, ki jih na Pleteršnikovih dnevih predstavljajo strokovnjaki, ko razpravljajo o teoretičnih vprašanjih in praktičnih rešitvah v slovaropisju, pa so pomemben prispevek pri pripravi novega slovarja slovenskega knjižnega jezika. Danes smo videli najnovejši dosežek slovenskega slovaropisja, razširjeno in izpopolnjeno izdajo SSKJ-ja, pripravlja pa se tudi veliki projekt, tj. sestava novega sodobnega slovarja knjižnega jezika. Gre za veliko delo, ki ga mora in zmore primerno in na dovolj strokovni ravni opraviti le inštitucija, ki je za to v Sloveniji tudi poklicana, tj. ZRC SAZU in njen Inštitut za slovenski jezik Frana Ramovša pod vodstvom dr. Marka Snoja. V medijih se zadnje čase za tako delo ponujajo tudi druge, privatne ustanove, ki poskušajo prepričati državo oz. financerja, da jih prepozna za primerne. Pri tem se je razvila prava mala medijska vojna, v kateri se želi »priti do svojega kosa pogače«, tj. do deleža denarja iz proračunske blagajne - prepričan sem, da taka pot ni prava, da se Pleteršnik obrača v grobu in da je za temeljne priročnike slovenskega knjižnega jezika (slovnica, slovar in pravopis) odgovoren SAZU s svojim ZRC in Inštitutom za slovenski jezik, ki združuje naše najboljše strokovnjake in poznavalce slovaropisnega dela, ki ima edini dovolj potrebnega znanja, izkušenj in kadrov za tako obsežno in nacionalno pomembno delo. Edina prava pot, ki do takega slovarja vodi, je SAZU-jeva, ali povedano drugače - sodobni slovar slovenskega knjižnega jezika mora nastati v okviru ZRC SAZU, tj. pod strokovnim vodstvom Inštituta za slovenski jezik Frana Ramovša, ki bo k delu pritegnil tudi druge slovenske raziskovalce in poznavalce slovaropisnih vprašanj. Gre za temeljno delo, ki ne more nastati čez noč, ki ga je potrebno graditi na trdnih in preizkušenih teoretičnih temeljih, premišljeno usmerjati in pri tem dopolnjevati izkušnje iz preteklosti s čim širšim in v stroki uveljavljenim sodobnim znanjem in izkušnjami v slovaropisni stroki. Do takega slovarja ne vodijo bližnjice, ne da se ga napisati v letu ali dveh in ne more nastajati zgolj in samo na korpusu, pridobljenem predvsem z izpisovanjem iz medijev. Tak korpus je lahko dobra podlaga za slovenski publicistični slovar, ki ga v Sloveniji prav tako potrebujemo, temeljno delo našega slovaropisja, ki izhaja iz Pleteršnikove dediščine in bo vreden naslednik SSKJ-ja, pa mora nastati v okviru SAZU-ja. Nepotrebni medijski nastopi ob pripravah na novi slovar slovenskega knjižnega jezika nas prepričujejo, da je nad znanostjo človek; ne le ideja, stališče, ampak želja človeka, da dela pošteno in da je pri tem zavezan svoji in znanstveni resnici ... Delo za novi slovar slovenskega knjižnega jezika 
zahteva veliko časa, treba se je spoprijeti s problemi, se učiti, študirati. Ne le prepir o tem, kdo ima boljše dokaze, ampak spoznanje, zavedanje, da se na začetku in koncu stvari postavijo na pravo mesto. In pri tem trdno in odločno podpiram strokovnjake z Inštituta za slovenski jezik Frana Ramovša, ZRC SAZU.

Pleteršnikove Pišece so z raziskavami, opravljenimi na Pleteršnikovih dnevih, takemu nacionalnemu projektu nedvomno lahko $\mathrm{v}$ pomoč, hkrati pa je potrebno na občinski in državni ravni zagotoviti osnovne pogoje, da se bo to slovensko slovaropisno središče lahko še naprej razvijalo in nadaljevalo Pleteršnikovo tradicijo. Društvo za varovanje maternega jezika in kulturne dediščine Maksa Pleteršnika ter Strokovni odbor Maksa Pleteršnika bosta težko izpeljala projekte, ki jih načrtujeta v prihodnosti, če zato ne bo več lokalnega, občinskega ali državnega posluha. Pleteršnikova domačija potrebuje širšo promocijo, v Pišece želimo pripeljati več učencev in dijakov, ki bodo ob Pleteršniku spoznavali pomen in vlogo maternega jezika v globalnem svetu, na simpozije želimo vabiti najboljše strokovnjake, predvsem pa znanje, ki ga pri tem izmenjujemo, predstaviti najširši zainteresirani javnosti, tako da dovolj hitro izdajamo monografije s Pleteršnikovih dnevov. Leto in več stare objave niso tako uspešne in odmevne, stroka se danes prehitro razvija, da bi lahko na take zbornike čakali več let. Imamo znanje, imamo izkušnje, pripravljeni smo delati, potrebujemo pa več posluha in pomoči pri širjenju našega znanja $v$ svet. Upam in verjamem, da se bo ob ohranjanju Pleteršnikove misli v prihodnje našlo več posluha in sredstev za delo Pleteršnikovega društva in Strokovnega odbora. Cena promocije, ki jo s tem dobi kraj, občina, država, je tako rekoč minimalna, narodu, ki ne vlaga ali ne želi vlagati v znanje, v svoj jezik in kulturo, pa se ne obeta nič dobrega. Šparanje pri jeziku se ni obneslo nobeni državi (Šparovc cehovca najde! - Kdor špara, vedno zapitek plača!), še zlasti ne v času, ko anglizacija iz političnih in gospodarskih krogov nasilno in premalo premišljeno prodira tudi $\mathrm{v}$ univerzitetni prostor, raziskovanje in izobraževanje. Izguba ene izmed funkcijskih zvrsti jezika, v našem primeru izguba znanstvenega in strokovnega jezika, pomeni začetek konca nekega jezika. Kaj sploh še ostane »malim« v globalnem svetu in zgrešenem bolonjskem univerzitetnem prostoru? Ali postajamo (ne)zavedno grobarji jezika, ki ga je Maks Pleteršnik tako ponosno ustoličil med kulturne jezike sodobne Evrope?

Čeprav smo v Pleteršnikovih Pišecah, pa si v nadaljevanju izbiram še enega Štajerca, Pleteršnikovega starejšega znamenitega Slovenca, Slomška, s katerim želim opozoriti na pomen slovenskega jezika v znanosti in globalnem okolju.

Eno izmed načel, ki ga je Slomšek v Mihi Sancta et cara izpeljal iz Pavlove misli: »Oznanjaj, pomagaj, deli dobrote«, je tudi konkretna skrb za slovenski jezik: »Slovenščino skrbno neguj v Božjo čast in v blagor slovenstva!« Danes, v času globalizacije ter nepremišljeno zaletavega jezikovnega odpadništva na področju šolstva in znanosti, postaja Slomškovo duhovno sporočilo še kako pomembno in aktualno. Opozarja nas na moralnost na vseh področjih, tudi in predvsem v znanosti in šolstvu ter njenem odnosu do najintimnejšega, kar nam je bilo dano in kar imamo, tj. do maternega jezika. Slomšek je to podkrepil z mislijo iz Lukovega evangelija 12,48: Komur so veliko zaupali, bodo od njega toliko več terjali $(\mathrm{Lk}, 12,48)$ 
Nezlagano in močno doživljanje odgovornosti, ki nam je zaupana na katerem koli področju, tudi odgovornost do slovenskega jezika v znanosti in šolstvu, je Slomšek postavil na vrh vsega »svetega in dragega«, tako da je v Skrbi za moralnost to misel še razvil in je kot sredstvo za ohranitev čistosti postavil: » Študij slovenščine kot drugotna zaposlitev, da se ne bi iz brezdelja porodila poželjivost.«

Tako odgovorno je Slomšek razmišljal o slovenskem jeziku tudi na predavanjih slovenščine v celovškem semenišču: »Sv. Ciril in Metod, žlahtna vučenika, sta previdela, da ni mogoče poprej Slovencam luč nebeške in pozemelske vednosti prav peržgati, dokler svečnik, tj. jezik slovenskiga govorja obstojočiga dna nima. Sakaj preden zidar dnu perpravi, potem bodeš terdnu hišo zidal, vučenik, aku poprej vednost tvojga govorja si osvoji, potem bodeš lehko s njim luč praviga podvučenja razširal.«

Slomšek je odgovornost do slovenskega jezika v skrbi za duhovno oblikovanje strnil v pravilo, ki bi se ga danes morali zavedati vsi slovenski znanstveniki in raziskovalci: »Operare - non quod jucundum, sed guod magis necessarium «. V Mihi sancta et cara je zato njegovo splošno pravilo v skrbi za stvari, ki zavzemajo vse, glede rabe slovenskega jezika v znanosti in nasploh optimistično - izhajajoč iz velike odgovornosti Slomšek optimistično spodbuja: »Potrpi in zdrži!«

Pred nami je veliko nedokončanega dela v dialektologiji in zgodovini slovenskega jezika, nerešenih in vedno novih normativnih vprašanj, ki nam jih nalaga sodobno slovensko jezikoslovje, pojavljajo se vedno novi izzivi, povezani z jezikovnim načrtovanjem in jezikovno politiko ..., znova in znova je potrebno ostriti slovensko jezikoslovno misel, kot je to leta in leta počel Maks Pleteršnik. V Pišecah zato ohranjamo spomin na njegovo jezikoslovno misel in odkrivanje jezika, ki ga imamo, ki ga moramo razvijati, ki ga moramo poznati bolj kot vse druge jezike, ki nas povezuje in ki nam zastavlja vprašanja in prinaša rešitve.

Naj spomnim še na razmišljanje velikega Pleteršnikovega sodobnik Stanislava Škrabca: »Književni jezik je orodje literaturi, pisava orodje književnega jezika; kolikor bolje bo orodje, toliko bolje bo delo, ki se bo delalo z njim. Seveda pa ne sme vsaki orodja popravljati in prenarejati, to se mora prepustiti tistim, ki imajo za ta posel potrebno znanje. Drugi pa naj skrbe, da bodo z najboljšim orodjem pridno delali vsak svoje delo.»

S temi Škrabčevimi besedami se v imenu Filozofske fakultete Univerze v Mariboru in Strokovnega odbora Maksa Pleteršnika zahvaljujem vsem, ki si v Pišecah prizadevate, da orodje, za katerega sta tako predano skrbela Maks Pleteršnik in Stanislav Škrabec, ne leži pozabljeno v kotu, ampak se o njem pogovarjajo strokovnjaki, ga raziskujejo, primerjajo z današnjim in tako nadaljujejo Pleteršnikovo delo. Prisrčna hvala gospe Marjanci Ogorevc in gospodu Martinu Dušiču, šoli in Pišečanom, ki ves čas z velikim spoštovanjem do Maksa Pleteršnika skrbite za ohranjanje spomina na njegovo življenje in delo.

Marko Jesenšek 


\section{PRED IZIDOM DRUGE IZDAJE SLOVARJA SLOVENSKega KNJIŽNEGA JEZIKA IN ODPRTJEM SLOVARSKEGA SPLETIŠČA FRAN}

(Bežen prikaz v Pišecah, 2. oktobra 2014)

Slovaropisje na Slovenskem že od davnih časov zbuja več strasti kot pri sosednjih in primerljivih narodih. Naše besede je proti koncu 16. stoletja v svoj večjezični slovar uvrstil nemški leksikograf Hieronim Megiser, stoletje kasneje je Matija Kastelec napisal Latinsko-slovenski slovar, Gregor Vorenc ga je dokončal, a je ostal v rokopisu. Zares dokončala ga je šele Majda Merše, saj ga je po osnovni redakciji Jožeta Stabeja prav ona pripravila za objavo, in to v obrnjeni slovensko-latinski obliki. Razen Dalmatinovega registra Slovenci vse do konca 18. stoletja nismo imeli slovarja, ki bi imel slovenščino na prvem mestu. Leta 1781 izide Pohlinovo Tu malu besedishe treh jesikov in avtor, ki je slovar napisal iz žive potrebe, da bi tudi mi imeli svoj slovar, v uvodu zapiše: Sakaj sê nisè lubè Kraynz! She Jdavnej poprej doliusedęl, ter, koker bi pihnel, en cel popolnoma Dikzijonarium spisal? To zhast bi bil Tebi iz srca pervoshil. Pohlin je s tem ošvrknil vse, ki so želeli napisati slovar, a ga niso. Takole pravi v nadaljevanju: Inu mordej je Jhę merski eden od dvajftu lejt lésèm, kar smo fazhęli Kraynzi latinske zherke shpogàti, fazhel; ali kumej A B C spisal, se pak Shę tudi navelizhal, ter use skupej naenkrat na kol obęsèl.

Pohlinova ocena slovenskega slovaropisja je genialna in ne velja samo za nazaj, temveč tudi za prihodnja stoletja. Malo mlajši genialni um Valentin Vodnik je tudi začel pisati slovar, a ga ni dokončal. Pol stoletja za tem se dolgo niso mogli zediniti, kdo naj piše novi slovar. Gradivo so imeli Levstik, Caf, Miklošič, Erjavec in še mnogi drugi. Knezoškof Antonij Alojzij Wolf, ki je financiral nastajanje slovarja, je nalogo poveril Pleteršniku - jezikoslovcu, ki se je rodil na Prešernov 40. rojstni dan. Oblasti so imele prav: Pleteršnik se je doli usedel in dober dikcionarium v malo letih spisal.

Pleteršnikov slovar je dvojezični: slovenske besede razlaga z nemškimi prevedki, le izjemoma s slovenskim sinonimom ali razlago. Prvi slovenski razlagalni slovar je Glonarjev iz leta 1936, ki ga površna slovenska Wikipedija omenja samo v njegovi izbrani bibliografiji. Slovar ni bil dobro sprejet, čeprav za tiste čase sploh ni bil slab. In bil je naš prvi enojezični razlagalni, kar ni malo.

Čas po drugi svetovni vojni je, tako kot pri drugih kulturnih narodih, temeljno slovaropisje institucionaliziral. Proces se je začel že pred tem, saj je bila sestava slovarja knjižnega jezika že v tridesetih letih prejšnjega stoletja prva naloga takrat ustanavljajoče se akademije znanosti in umetnosti. Po vojni so se začele resne priprave na to veliko delo in zares dober slovar smo Slovenci dobivali v letih od 1970 do 1991, ko je v petih knjigah izhajal Slovar slovenskega knjižnega jezika. Leta 1994 je z nespremenjeno vsebino izšel še v eni knjigi, nekaj let kasneje na disketah in CD-ju, leta 2000 je izšla prva spletna izdaja, prav tako nespremenjena. Pred 14 leti so bili spletni slovarji še velika redkost, razen angleških in nemških skoraj ni bilo nobenega drugega, slovenski je pa bil. 
Ne bom govoril o težavah, ki so spremljale nastanek in pisanje SSKJ. Bilo jih je veliko, tudi nasprotnikov in zaničevalcev ni bilo malo, ampak vedno je tako, ko se dela kaj velikega. Ker je bil pojmovni svet druge polovice 20. stoletja, ko je nastajal SSKJ, precej drugačen od današnjega, in ker je tudi jezikoslovje v tem času prišlo do novih spoznanj, je SSKJ začel zastarevati. Ni še zastarel, je pa na tej poti. Ker vemo, da v današnjih razmerah v nekaj letih ni mogoče napisati novega slovarja knjižnega jezika, ki bi bil obsegovno in kakovostno dostojen naslednik SSKJ-ja, smo se na inštitutu odločili za pripravo njegove druge, dopolnjene in deloma prenovljene izdaje, ki je zdaj pred nami. Druga izdaja je izšla $\mathrm{v}$ dveh natisnjenih knjigah, dostopna pa je tudi na spletu, in sicer na naslovu www.sskj2.si, od 14. oktobra pa bo tudi del slovarskega spletišča Fran. Druga izdaja se od prve razlikuje v več pogledih in podrobnostih, glavne so tele:

1. 4521 je novih slovarskih sestavkov. $\mathrm{V}$ njih so opisane besede in besedne zveze, ki so se v slovenskem knjižnem jeziku uveljavile v obdobju po osamosvojitvi Slovenije, npr. porjavitev, tajkun, evro. Že prej znanim besedam, vključenim v prvo izdajo slovarja, je dodano 1517 novih pomenov. Pri opisu besede miška je dodan novejši pomen iz računalništva, pri tolarju pa pomen zdaj že nekdanje denarne enote Republike Slovenije. Poudariti je treba, da ob tem druga izdaja ohranja vse besede in pomene prve izdaje, zaradi česar slovar zaobjema bogastvo slovenskega besedja iz doslej najdaljšega obdobja - od druge polovice 19. stoletja do leta 2013.

2. Posodobljeni so pomenske razlage in zgledi rabe, ki so preživeli duh časa, kot ga je iz jezikovnega gradiva druge polovice 20. stoletja ulovila redakcija prve izdaje (nekatere so za današnji čas celo žaljive ali vsaj politično nekorektne), npr. cigan, prostitutka, transvestit, desničar, levičar, žid.

3. Iz podobnih razlogov je v najnujnejših primerih posodobljeno tudi označevanje, npr. kreten, bebav. Raba izrazov, značilnih za čas politične ureditve pred letom 1991, je označena z današnjega stališča, npr. maršalat, desetar. Ponovno oživljeni izrazi, ki so bili v prvi izdaji označeni, npr. kot kapitalistični, so v drugi izdaji na novo ovrednoteni, npr. delnica.

4. Samostalniki, ki označujejo ženske osebe, imajo polnopomenske razlage, npr. igralka, lastnica.

5. Posodobljene so naglasne značilnosti besed, npr. iglú, tandém, eskímski (prej prednostno íglu, tándem, éskimski), in izgovarjava, ki je v drugi izdaji navedena za celotno besedo, npr. jazzovski, augsburški, bestseller.

6. Uveljavljeni sta dve mlajši besedni vrsti, ki ju prva izdaja slovarja še ni označevala $\mathrm{z}$ besednovrstno oznako, tj. členek in povedkovnik.

Druga izdaja SSKJ torej podaljšuje življenjsko dobo tega slovarja. Z njegovo pomočjo je mogoče razumeti slovenske klasike 19. stoletja, Cankarja, predvojne pisce, čas po drugi svetovni vojni in besedila, ki so nastala v samostojni Sloveniji in Sloveniji kot članici EU. Zdaj imamo tajkune, računalniške miške, družabna omrežja, česar vsega v času priprave prve izdaje slovarja še ni bilo. V drugo izdajo smo smiselno vpletli večino besed iz Slovarja novejšega besedja, 
tem dodali še nekaj sto novih, približno 20 odstotkov slovarskih sestavkov prve izdaje pa je bilo spremenjenih, nekateri bolj, drugi manj. Splošnoslovaropisna skupina je prenovo pripravljala poldrugo leto.

SSKJ je naš temeljni informativno-normativni slovar; v njem najdemo mnogo besed, ne samo knjižnih, zato je treba slovarski sestavek vedno brati kot celoto. Samo iz celote namreč izvemo, ali je beseda knjižno nevtralna, pogovorna, morda celo vulgarna. Naj navedem dve besedi, ki se začneta $\mathrm{s} f$ in ju ima $\mathrm{SSKJ}^{2}$, a nista knjižno nevtralni, sta izrazito pogovorni, saj ju ne bi uporabili npr. pri pisanju kake prošnje: ful in fuzbal. Tisto, ki ste jo zdaj morda pričakovali, ima že prva izdaja.

Za dobršen del današnjih uporabnikov velja, da slovarje raje uporabljajo v računalniški obliki kot v klasično tiskani knjigi. Slovar je zato izšel tudi na spletu, dostopen je torej na računalnikih, tablicah in pametnih telefonih. A noben slovar ni popoln, tudi SSKJ ${ }^{2}$ ne. Če bomo v njem iskali kako zelo staro besedo, ki že davno ni več v rabi, npr. antverhar - ta je nekdaj pomenila »rokodelec« -, je ne bomo našli, prav tako v njem ne bomo našli kake zelo mlade, npr. selfi. Tudi kake ozko strokovne besede ne bomo našli, npr. posipnik, ki v farmaciji označuje »pripravo za nanašanje praškov na kožo s posipanjem«. Zato smo na inštitutu zasnovali slovarsko spletišče z imenom Fran (ime dolgujemo Franu Ramovšu, ustanovitelju našega inštituta, soustanovitelju Univerze v Ljubljani in SAZU in najpomembnejšemu slovenskemu jezikoslovcu 20. stoletja), v katerem bomo z enim iskalnikom lahko iskali po 20 slovarjih hkrati, obenem pa dobili tudi podatke iz jezikovnih svetovalnic in besedilnih korpusov. Spletišče bo začelo delovati 14. oktobra na naslovu www.fran.si. O njem bi lahko govoril zelo dolgo, a ne bom. Oglejte si ga čez dva tedna, ko bo na voljo. Povem naj le to, da bo vseboval prek pol milijona slovarskih sestavkov z verodostojno vsebino, da bomo poleg splošno znanih besed v njem našli tudi že davno pozabljene, npr. glavnja, samveč, pa tudi tako nove, kot npr. selfi, skike, za katere še ne vemo, ali se bodo uveljavile, kakor koli prenaredile ali zamrle.

Marko Snoj Inštitut za slovenski jezik Frana Ramovša, ZRC SAZU, Ljubljana

\section{GLASOSLOVNI IN OBLIKOSLOVNI PODATKI V SPLOŠNEM RAZLAGALNEM SLOVARJU}

Enojezični splošni razlagalni slovarji prinašajo različne vrste glasoslovnih in oblikoslovnih podatkov, kar je odvisno zlasti od naglasnih in oblikovnih značilnosti obravnavanega jezika. Za knjižno slovenščino, ki nima stalnega naglasnega mesta in pozna dve enakovredni vrsti naglaševanja, povrhu vsega pa je tudi oblikoslovno zelo bogata, je poleg onaglasitve slovarskih iztočnic, 
prikaza izgovarjave zelo smiselno tudi navajanje pregibnostno-naglasnih vzorcev.

Druga izdaja Slovarja slovenskega knjižnega jezika $\left(\mathrm{SSKJ}^{2}\right)$ prinaša med drugim tudi nekaj posodobitev glasoslovnih podatkov. Izgovorno nepredvidljive in težje predvidljive iztočnice imajo izgovor izpisan v celoti. Vse nepodomačeno zapisane iztočnice, pri katerih zakonitost ujemanja med črko in glasom, ki je sicer značilna za slovensko knjižno izreko, ni uresničena, niso onaglašene, naglas je naveden pri izpisu izgovarjave za oblikoslovnimi končaji med oglatima oklepajema. Vse podomačene oblike prevzetih besed so onaglašene (SSKJ: allégro [ale-], SSKJ ${ }^{2}$ : allegro [alégro]; SSKJ: angína péctoris [-kt-], $\mathrm{SSKJ}^{2}$ : angina pectoris [angína péktoris]; lizing tudi leasing -a [líz-], SSKJ ${ }^{2}$ : lízing tudi leasing [lízing-]). Pri prikazu izgovarjave so zabeležene tudi zvenečnostne premene in položajne različice fonema $v$ (basketball -a [báskedbol], wildovski -a -o [vájldounski]), v izglasju besede pa tovrstne premene nakazuje levostični vezaj (présing tudi pressing -a [présing-], solzàv -áva -o [sounzav-]). Spremenjeno je tudi naglasno znamenje nad samoglasnikoma $e$ in $o$ v položaju pred istozložnim ali raznozložnim $j$ oz. $v(u)$. V obeh navedenih primerih sta označena s strešico (vêjnat, brodôvje; vêja, obnôva).

$\mathrm{S}$ stališča sodobne jezikovne rabe, ki je bila ugotovljena z metodo anketiranja govorcev knjižnega jezika, so bile preučene tudi nekatere naglasne dvojnice iztočničnih enot, $\mathrm{s}$ čimer so bile ugotovljene tendence naglaševanja $\mathrm{v}$ sodobni knjižni slovenščini. Naj izpostavimo zgolj nekaj naglasnih sprememb, ki so se zgodile v času od prve do druge izdaje SSKJ: a) Pri besedju, tvorjenem s kratkonaglašeno pripono -ènt, opažamo v odvisnih sklonih prevlado široke kakovosti naglašenega samoglasnika, oblike z ozko kakovostjo $e$-ja se v sodobni knjižni slovenščini pojavljajo redkeje (SSKJ: absolvènt -ênta in -énta, SSKJ2: absolvènt -ênta tudi -énta). Večina novejših tovrstnih besed pozna le široko kakovost $e$-ja (energènt -ênta) ali pa se ozki naglašeni $e$ pojavlja kot manj navadna izgovorna dvojnica (repelènt -ênta tudi -énta). b) Pri nekaterih trizložnicah beležimo ustalitev naglasa na drugem zlogu, naglas na prvem zlogu je v sodobni knjižni slovenščini manj običajen (SSKJ: palúba in páluba -e, SSKJ²: palúba tudi páluba -e; SSKJ: dínamo tudi dinámo -a, $\mathrm{SSKJ}^{2}$ : dinámo tudi dínamo -a). c) Pri prevzetih dvozložnicah, ki se končujejo na nenaglašeni - $u$, opažamo pomik naglasa (SSKJ: ému tudi emú -ja, SSKJ²: emú tudi ému -ja; SSKJ: íglu in iglú -ja, SSKJ²: iglú tudi íglu -ja; SSKJ: zebú -ja; SSKJ2: zebú tudi zébu -ja). Rezultati anket nakazujejo, da je tak razvoj značilen tudi za novejše besede tega tipa $\left(\mathrm{SSKJ}^{2}\right.$ : gurú tudi gúru -ja, haikú tudi háiku -ja).

Pri pripravi druge izdaje Slovarja slovenskega knjižnega jezika smo opazili tudi nekaj iztočničnih enot, pri katerih v prvi izdaji še ni bilo izkazanega dvojničnega naglaševanja, druga pa prinaša podatke o naglasnih dvojnicah, npr. SSKJ: katámaran -a, SSKJ ${ }^{2}$ : katamarán tudi katámaran -a. Ugotovljen naglasni razvoj potrjuje tudi novejša beseda trimarán, ki je uvrščena v Sprotni slovar slovenskega jezika (SSSJ) in se naglašuje le na zadnjem zlogu. Do sprememb na naglasni ravni je prišlo tudi pri nekaterih pridevnikih, kot je denimo dohodkoven (SSKJ: dohódkoven -vna -o, SSKJ²: dohodkôven tudi dohódkoven -vna 
-o), kjer v sodobni slovenščini pogosto prihaja do pomika naglasa. Nekateri tovrstni pridevniki izkazujejo dvojnično naglaševanje že v prvi izdaji SSKJ-ja (npr. kosoven, popkoven, skladoven, slikoven, stavkoven, znakoven, zvokoven), pri drugih pa dvojničnega naglaševanja v času nastajanja SSKJ-ja še ni bilo (npr. dohodkoven, enozvezkoven, listkoven, načinoven, podatkoven). V drugi izdaji je naglasno mesto pri teh pridevnikih usklajeno s tendencami naglaševanja v sodobni knjižni slovenščini; pri nekaterih pridevnikih je pomik naglasa že popolnoma uveljavljen in oblika brez pomika naglasa postopno izginja iz rabe, pri drugih pa se oblika s pomaknjenim naglasom šele uveljavlja oz. soobstaja enakovredno z obliko brez pomaknjenega naglasa.

Novi temeljni informativno-normativni razlagalni slovar slovenskega knjižnega jezika bo prinašal podatke o jakostnem in tonemskem naglasu, izgovarjavi in pregibnostno-naglasnih vzorcih knjižne slovenščine. Glasoslovni in oblikoslovni podatki bodo prikazani v zavihku Izgovarjava in oblike. Najprej bo naveden jakostno in tonemsko onaglašeni izgovor iztočnične enote, kjer bo s klikom na ikono zvočnika uporabnik lahko dostopal tudi do studijskega posnetka izgovarjave. Prikazu izgovora bodo sledili pregibnostno-naglasni vzorci, ki bodo vsebovali tudi vse ugotovljene naglasne in oblikovne dvojnice. Vsi vzorci bodo prikazani tudi v tiskani različici slovarja, in sicer v slovarskem uvodu, na koncu zaglavja slovarskega sestavka pa bodo navedene zgolj številčno-črkovne oznake, ki bodo nakazovale ustrezni pregibnostno-naglasni vzorec. Številčno-črkovno oznako bodo imele tudi nekatere nepregibne besedne vrste, ki so v gradivu izpričane v več različnih oblikah.

Pregibnostno-naglasni vzorci bodo razvrščeni na osnovi tonemskega naglasa in oblikovnih posebnosti posameznih pregibnih besednih vrst. Prinašali bodo podatke za vse sklonske oblike, vsa števila, vse spole in osebe. Pri pridevniški sklanjatvi bodo poleg osnovne pridevniške sklanjatve prikazane tudi stopnjevane oblike. V okviru vzorcev za glagol bodo obravnavane nezložene osebne in neosebne glagolske oblike. Glagoli bodo glede na nedoločniško in sedanjiško pripono razdeljeni v sedem glagolskih vrst, znotraj teh vrst pa še na posamezne naglasne tipe, oblikovane na podlagi tonemskega naglasa nedoločnika in prve ter druge osebe ednine.

Pri pripravi pregibnostno-naglasnih vzorcev bo posebna pozornost namenjena tonemskemu naglasu, ki ga slovar sodobne knjižne slovenščine nikakor ne sme prezreti. Prvi zapis o tonemskem naglasu imamo z začetka 19. stoletja, ko je Valentin Vodnik v svoji slovnici Pisemnost ali gramatika za perve šole ponazoril pomenskorazločevalno vlogo slovenskih tonemov na dveh znanih protistavah Jutrišnji dân nam kruh še ni dán in Ga popade za vrât in nese do vrát. O tonemskem naglaševanju so pisali številni domači in tuji jezikoslovci. Kot zanimivost dodajamo, da je v Slovensko-nemškem slovarju M. Pleteršnika tonemski naglas del pisne podobe iztočnice. Pleteršnik jakostnega naglaševanja niti ne omenja, kar kaže, da mu je tonemsko naglaševanje predstavljalo pomemben del slovenske knjižne norme. V poskusnem snopiču Slovarja slovenskega knjižnega jezika iz leta 1964 je bil tonemski naglas naveden na zapisu izgovarjave, ki je bila prikazana v celoti. V Slovarju slovenskega knjižnega jezika pa je tonemsko 
naglaševanje prikazano na koncu zaglavja med okroglima oklepajema, medtem ko so v uvodu slovarja navedene izčrpne Sheme za tonemski naglas, ki jih je izdelal J. Rigler.

Tonemski naglas ima v sodobni slovenščini v mnogo primerih pomenskorazločevalno vlogo, ki jo izkazujejo tako izhodiščne slovarske oblike uslovarjenih besed (válček»ples«, vâlček »manjšalnica od val«; šíbica »manjšalnica od šiba«, šîbica »vžigalica«) kot tudi celotni pregibnostno-naglasnih vzorci posameznih pregibnih besednih vrst (sọ́di »glagol soditi«, sộdi »samostalnik sod«; máčka »rodilniška oblika od samostalnika máček«, mâčka »mačja samica«). Poleg nesporne vrednosti, ki ga ima tonemsko naglaševanje za jezikoslovne raziskave, prinaša tudi dragocene podatke o zgodovini slovenskega (knjižnega) jezika. Tako denimo samostalnik óče v molitvi ôče näš v knjižni slovenščini ohranja visoki ton (cirkumfleks), kar predstavlja ostanek nekdanjega zvalnika.

J. Rigler je pri ugotavljanju tonemskega naglasa v knjižni slovenščini uporabljal metodo anketiranja tonemsko govorečih izobražencev. Zapis tonema ni bil zgolj rezultat anket, ampak je bila izvedena tudi določena sistemizacija rešitev. Novi slovar slovenskega knjižnega jezika bo prinašal tendence tonemskega naglaševanja v sodobni knjižni slovenščini, ki bodo prav tako ugotovljene $\mathrm{Z}$ metodo anketiranja tonemskih govorcev knjižne slovenščine. V prvi vrsti bo ugotovljena sodobna jezikovna raba tonemskih dvojnic, in sicer zlasti tistih, ki so v Shemah za tonemski naglas povezane s kvalifikatorjem »ali tudi«.

Merila pri izboru anketirancev so večplastna. Anketirani bodo tonemski govorci različnih starostnih skupin, ki so v stiku z govorjenim knjižnim jezikom in prihajajo iz osrednjega slovenskega narečnega prostora. Anketirance bodo sestavljali ljudje različnih poklicev, tudi javni govorci, ki so večinoma govorno izobraženi in imajo pomemben vpliv na oblikovanje knjižne norme. Raziskava bo osnovana na branih, vnaprej pripravljenih besedilih, kar predstavlja enega izmed pomembnih položajev rabe govorjenega knjižnega jezika.

Onaglašeni pregibnostno-naglasni vzorci za vse pregibne besedne vrste predstavljajo noviteto in so tako z jezikoslovnega kot uporabniškega vidika pomemben prispevek k sodobnemu slovenskemu slovaropisju in večji obvestilnosti slovarja, saj uporabniku slovarja na pregleden način prinašajo več vrst glasoslovnih in oblikoslovnih podatkov o obravnavani iztočnični enoti (jakostni in tonemski naglas, kolikostne in kakovostne premene naglašenega samoglasnika, tonemske premene pri pregibanju, ustrezno okvalificirane naglasne in oblikovne dvojnice, podatke o morebitnem samomnožinskem ali samoedninskem pregibanju, podatke o kategoriji živosti ...). Natančen in sistematičen opis pravorečja in oblikoslovja, ki bo obenem skušal podati čim bolj objektivno podobo jezikovnega stanja sodobne knjižne slovenščine, predstavlja tudi osnovo za nadaljnje naglasoslovne in oblikoslovne raziskave slovenskega (govorjenega) knjižnega jezika.

Tanja Mirtič 


\section{SPROTNI SLOVAR SLOVENSKEGA JEZIKA}

Sprotni slovar slovenskega jezika (SSSJ) predstavlja popis novega, še neuslovarjenega gradiva, ki ga (ob zaključenih, gradivno zaokroženih slovarjih, kot je npr. najnovejša druga, dopolnjena in deloma prenovljena izdaja SSKJ, tj. SSKJ ${ }^{2}$ ) na Inštitutu za slovenski jezik Frana Ramovša - med drugim tudi na pobudo uporabnikov oz. ob odzivih na njihova vprašanja $\mathrm{v}$ jezikovni svetovalnici - redno zbiramo in analiziramo. Lahko bi rekli, da je SSSJ neke vrste »čakalnica«, v kateri je besedje opisano v svojih temeljnih značilnostih in je v takem opisu na voljo uporabnikom. Čas bo pokazal, ali bodo posamezne iztočnice prešle v normativne oz. obširnejše razlagalne slovarje, kjer bodo opisane še natančneje. Iz tega tudi sledi, da je SSSJ slovar predvsem informativne narave. SSSJ zaenkrat obsega 225 iztočnic; od 14. 10. 2014 bo prosto dostopen na Franu, slovarskem spletišču Inštituta za slovenski jezik Frana Ramovša ZRC SAZU (www.fran.si). SSSJ bo dopolnjevan predvidoma na pol leta.

SSSJ je zasnovan kot uporabniku prijazen rastoči slovar informativne narave, ki zbira živo, a v slovarjih (praviloma) še ne zabeleženo novejše (dokaj pogosto izrazito aktualno) besedje in prikazuje njegove temeljne pomenske, slovnične in pragmatične lastnosti. Jedro geslovnika izhodiščne različice slovarja predstavlja še neuslovarjeno besedje, katerega rabo v zadnjih letih potrjuje korpusno gradivo, geslovnik pa je bil dopolnjen $\mathrm{z}$ besedjem, po katerem so uporabniki neuspešno poizvedovali v slovarjih na inštitutski spletni strani http://bos.zrc-sazu.si (upoštevani so obiski iz zadnjih štirih let in pol). Prav tako izhodiščni geslovnik zajema besedje, ki ga obstoječi (časovno zamejeni) korpusi slovenščine zaenkrat še ne prinašajo, raba nove besede pa je kljub temu bila zabeležena $\mathrm{v}$ drugih (zlasti elektronskih) virih. Na podoben način se bo geslovnik dopolnjeval tudi v prihodnosti - poudarek bo na vključitvi besedja, ki izkazuje pojmovno in poimenovalno novo. Novo besedje se bo SSSJ dodajalo predvidoma na pol leta.

SSSJ ni normativni slovar, kar pomeni, da nima usmerjevalne vloge. Prinaša namreč temeljne podatke o pomenskih lastnostih in rabi besedja, ki v slovenskem jeziku še nima dolge življenjske dobe. Kot iztočnica je navadno navedena v rabi pogostejša oblika besede. Pri prevzetih besedah je ob uravnoteženosti rabe načeloma najprej navedena podomačena beseda, vendar pa to ne pomeni, da so druge navedene oblike manj ustrezne, saj se (kot že omenjeno) do tega vprašanja SSSJ ne opredeljuje. Načelo normativne neusmerjevalnosti velja - če seveda ni že vsak opis jezika na določen način normativen - za vse dele slovarskega sestavka, vključno z izgovornimi dvojnicami in s sinonimi, ki ponekod stojijo za razlago. Vsi slovarski podatki so tako primarno informativne narave - jezikovnemu uporabniku so v pomoč pri razumevanju pojmovne vsebine iztočnice.

Kljub odpovedi knjižnojezikovnemu normiranju slovar na pomenski ravni označuje vezanost rabe besede na katero od jezikovnih zvrsti podobno kot Slovar slovenskega knjižnega jezika, denimo na izhodiščno strokovni jezik pri izvorno terminološkem besedju oz. pomenih, na pogovorni jezik, sleng oziroma 
na stilno zaznamovanost (npr. ekspresivnost, slabšalnost). Brez vsaj okvirnih podatkov o zvrstnosti oz. o tipičnih okoliščinah rabe besede bi bil namreč njen opis pomanjkljiv, lahko celo zavajajoč. Vsako vrednotenje te vrste pa je seveda mogoče le v odnosu do knjižnega jezika. oz. knjižnojezikovne norme. Pri tem knjižnojezikovno normo razumemo kot osrednji, stabilni, postopoma spreminjajoči se (in zato v prožni stabilnosti ustrezno normiran) del jezika v dejanski rabi, ki povezuje vse njegove govorce, hkrati pa je kot posrednik (jezikovne) tradicije temelj za prihodnji jezikovni razvoj in z njim povezano presojo jezikovnih pojavov.

Od besed, ki jih v obstoječih korpusih ni ali pa so zelo redke in omejene predvsem na zadnja leta, ki so v korpusih gradivno še pokrita, SSSJ med drugim prinaša zlasti iz angleščine prevzete besede (npr. glamping, selfness, skike, sup). Nekatere od teh besed nastopajo tudi v podomačeni obliki (npr. selfi), vendar pa večinoma še nimajo domačega ustreznika. Pri teh besedah imajo uporabniki možnost predlagati domače ustreznike, ki jih uporabljajo ali bi jih želeli uporabljati; prav tako se lahko do že obstoječih predlogov (drugih uporabnikov) tudi opredelijo. Cilj takšne možnosti je povečati interaktivnost slovarja in okrepiti zavedanje govorcev o njihovem vplivu na jezikovno rabo, preko katere lahko posledično sodelujejo pri normiranju slovenskega besedja.

Poleg besed, ki v slovarjih slovenščine doslej še niso bile zabeležene (npr. bulgur, dred, falafel, gamber, goji, komunajzar, multifunkcijski, natreniran, odpikati, všeček), SSSJ prinaša nekatere nove pomene že uslovarjenega besedja (npr. pri epski, košarica, replika, sprehajalec, vroč), nove stalne besedne zveze (npr. dopust: dopust za nego in varstvo otroka, hišica: premična hišica, kapica: socialna kapica, konsolidacija: konsolidacija javnih financ, pohod: strelski pohod) in frazeologijo (hotel: hotel mama, svinja: sanja svinja o koruzi, žoga: na prvo žogo), pri že uslovarjenih zvezah pa lahko tudi nove pomene.

Zgradba SSSJ je zaradi tipa in značilnosti besedja, ki ga slovar prinaša, dokaj preprosta, prikaz podatkov pa uporabniku prijazen. Zgledi rabe so npr. največ trije (navadno kolokacije, če le dovolj pogoste in povedne, v nasprotnem primeru je zgled stavčni; mogoča je tudi kombinacija kolokacijskih in stavčnih zgledov; v frazeološkem razdelku ter pri medmetih in členkih so vsi zgledi stavčni, drugod izjemoma). Pomensko neprozorne nefrazeološke stalne besedne zveze (tj. take, katerih pomen ni le preprosta vsota pomenov njihovih sestavin) so zbrane v skupnem razdelku stalnih besednih zvez (in tu po potrebi zvrstno označene). Vsa frazeologija je prav tako zbrana na enem mestu, tj. v frazeološkem razdelku.

Pomemben prispevek SSSJ so sistematično in pregledno prikazane oblike vseh v slovar sprejetih besed. Oblike, v katerih se beseda pojavlja (npr. pri samostalniku v vseh sklonih in številih, pri pridevniku poleg tega še v vseh spolih, pri glagolu v vseh osebah in deležniku na -l), so izpisane v celoti. Če se beseda pojavlja le v enem številu, so navedene oblike le za to število, npr. pri etažnosti ali posesivnosti le ednina. Prav tako sta v vseh iztočnicah prikazana tako jakostni kot tonemski naglas, izgovor pa je naveden za vse iztočnice in izpisan v celoti. Pri izgovoru so prikazane tudi naglasne dvojnice. 
Vrstni pridevniki, prislovi, (izvorno) glagolniki in deležniki imajo v SSSJ polne razlage (v katerih seveda se kaže odnos z njihovim izhodiščem, lahko pa je prisoten tudi manjši premik, npr. v odnosu med natrenirati in natreniran).

Ob prvi javni predstavitvi SSSJ v okviru slovaropisne okrogle mize na Pleteršnikovih dnevih v Pišecah dodajmo še zanimivost, ki jo izpostavlja primerjava slovarjev iz različnih obdobij slovenskega jezika, kakor jo z enim klikom omogoča Fran (slovarsko spletišče Inštituta za slovenski jezik Frana Ramovša ZRC SAZU). Gre za homonimijo (naključni sovpad tako zapisa kot izgovora besede ob pomensko popolnoma nepovezani pojmovni vsebini) med Pleteršnikovim slovarjem in SSSJ, in sicer pri besedi krapar: pri Pleteršniku je to »der Krapfenbäcker« (torej tisti, ki peče krape > krofe), v SSSJ pa »kdor lovi krape, navadno v prostem času, za sprostitev« (torej ribe krape). Zanimiva homonimija, ki je brez Frana, najnovejšega slovarskega spletišča Inštituta za slovenski jezik Frana Ramovša ZRC SAZU, ne bi tako hitro (ali pa sploh ne) opazili.

Vse to pomeni, da bo SSSJ deloval v nenehni interakciji z drugimi slovarji na omenjenem inštitutskem slovarskem spletišču in jih kljub svoji trenutni majhnosti smiselno dopolnjeval. Prav tako bo, kot že omenjeno na začetku, predstavljal svojevrstno čakalnico besed, ki bodo morebiti našle mesto tudi v obširnejših novonastajajočih razlagalnih slovarjih, kjer bodo lahko natančneje ovrednotene tudi normativno.

VIRI

Krvina, Domen: Sprotni slovar slovenskega jezika, različica 1.0, www.fran.si, dostop 14. 10. 2014

Domen Krvina Inštitut za slovenski jezik Frana Ramovša, ZRC SAZU, Ljubljana

\section{SLOVARJU O SLOVARJU Od PleteršnikA do SSKJ ${ }^{2}$}

Ob izidu osveženega SSKJ-ja, Slovarja slovenskega knjižnega jezika, Druga, dopolnjena in deloma prenovljena izdaja (SAZU in ZRC, Ljubljana: Cankarjeva založba, 2014), ki je neizmerno hitro v elegantni obleki in lični obliki že prišel med bralce, sem vzradoščena odprla drugi zvezek novega SSKJ-ja in strokovno obremenjena izbrala iztočnico, ki jo vsebuje tudi naslov: slovar, ki me s svojo enosmerno razlago že pred 18 leti, ko sem začela poučevati zgodovinsko besedoslovje, ni zadovoljila, saj ne zajame vseh vrst predmetnosti, temveč le osnovno obliko slovarja, tj. v knjižni obliki in z abecedno urejenostjo. Zato sem vsaj zdaj v računalniški in elektronskim medijem naklonjeni dobi pričakovala posodobljeno razlago iztočnice slovar. Ob primerjanju slovarskih sestavkov s to iztočnico v obeh SSKJ-jih so opazne nekatere uspešne posodobitvene spre- 
membe, toda ne $\mathrm{v}$ razlagi. Je za to kriva kovačeva bosa kobila ali pa so bila upoštevana starejša slovaropisna vodila? V SSKJ ${ }^{2}$ ostaja nespremenjena: »slovár -ja m (á) 1. knjiga, v kateri so besede razvrščene po abecedi in pojasnjene«. Po tej razlagi si vse besedne zbirke, ki niso v samostojni knjižni obliki in niso abecedno razvrščene, ne zaslužijo tega iz ruščine prevzetega imena, za katerega se moramo zahvaliti jezikoslovcu Valentinu Vodniku in njegovim naslednikom, ki so ga sprejeli in utrdili, niti si ne zaslužijo slovenskega, saj je za besednjak v obeh navedena ista razlaga. Mednje ne uvršča niti slovarjev na zapisljivem disku niti spletnih slovarjev niti elektronskega slovarja ali slovarčkov k drugim delom (podpomen »na koncu knjige je slovar« $\mathrm{z}$ razlago »seznam s tako razvrščenimi in pojasnjenimi besedami« se sicer skriva za količkom, ki označuje pomenski odtenek) niti pojmovnih, slikovnih idr. slovarjev, kaj šele Prosto dostopnih slovarjev in drugih prevajalskih pripomočkov za več kot 40 jezikov z že več kot 1000 naslovi (http://www.evroterm.gov.si/slovar/index.html). Tudi pomanjševalnica slovarček ima zaradi sklicevanja na iztočnico slovar enako pomensko opredelitev. V nemškem besedoslovju je takšna razlaga opredeljena kot ozka in preprosta, kot »eine naive Definition« (Ch. Schwarze, D. Wunderlich, Handbuch der Lexikologie, Darmstadt: Athenäum Verlag, 1985, 369), ker ne upošteva raznolikosti pojavnih oblik slovarjev. Slovar ne vsebuje le besed, ampak tudi morfeme, ni samo knjiga, ni samo abecedno urejen in ne vsebuje nujno razlag. Zato ponuja naslednjo kompleksno, toda premalo zgoščeno razlago, ki upošteva različnost medijev, uporabnikov, podatkov in omogoča hiter dostop do njih: »Das WÖRTERBUCH ist eine durch ein bestimmtes Medium präsentierte Sammlung von lexikalischen Einheiten (vor allem Wörtern), zu denen für einen bestimmten Benutzer bestimmte Informationen gegeben werden, die so geordnet sein müssen, daß ein rascher Zugang zur Einzelinformation möglich ist.« (1985: 369). Če bi razločevalne sestavine strnili, bi se prevod glasil: »Slovar je v nekem/določenem mediju predstavljena zbirka leksemov, urejena tako, da uporabniku omogoča hiter dostop do posameznih podatkov.«

Neopredeljenost, splošnost in različnost izraža poljubnostni zaimek »kakršen koli«, nedoločni zaimek neki, tudi pridevnik določen s pomenom 'poljuben'.

Ta načela upošteva razlaga, zapisana v Enciklopediji slovenskega jezika (1992) J. Toporišiča: »Kakršna koli zbirka besed, večinoma pa po kakšnem načelu urejena, npr. po abecedi besed (besednih družin) bodisi kot celotna gmota (npr. Megiserjev slovar 1592) ali kot oblikoslovno deljena (Bohoričevi slovarčki v slovnici 1584 v 6 razdelkih «/.../, ki je leksikonsko informativna, saj navaja dve obliki slovarjev iz začetkov slovenskega slovaropisja v 16. stoletju. Nato iztočnico opredeli glede na različne načine navajanja pomena: »Slovar večinoma podaja pomen besed, bodisi s prevodom v kak(e) $\operatorname{drug}(\mathrm{e})$ jezik(e) ali $\mathrm{z}$ opisom pomenov v istem (ali drugem) jeziku « in omenja prvi opisni slovar J. Glonarja (1935) ter »drugi veliko obsežnejši akademijski SSKJ (1970-1991)«, od starejših slovarjev na koncu še »najimenitnejša«, »t. i. Wolfova M. Cigaleta Deutsch-slovenisches Wörterbuch (1860) in Pleteršnikov Slovensko-nemški slovar (1894-1895).« Nadpomenska zveza (genus proximum) je v njej namesto knjiga samostalniška zveza zbirka besed, ki ustrezneje določa pomen te 
besedilne vrste in zajame vse vrste slovaropisja, zato se pri navajanju razločevalnih sestavin (differentia specifica) ne omejuje na en sam medij in način razvrstitve besed, ampak izraža njuno poljubnost.

Pri primerjavi med $\mathrm{SSKJ}^{1}$ in $\mathrm{SSKJ}^{2}$ so opazne spremembe tudi med vrstami slovarjev: med splošnimi vrstami je dodana za tehničnim še nova oblika slovarja: »elektronski slovar slovar v elektronski izdaji«. Zveza enozvezkovni slovar je bila prestavljena za dodano zvezo elektronski slovar (v SSKJ ${ }^{1}$ je bila navedena že za enojezičnim slovarjem) in je pridobila stavčno razlago (»slovar, ki navadno po združitvi predhodnih $v$ daljšem časovnem obdobju izdanih posameznih delov, izide v enem zvezku, eni knjigi«). Med jezikoslovno označenimi naštetimi vrstami slovarjev pred odzadnjim najdemo še sopomensko zvezo obrnjeni slovar z ustreznico odzadnji slovar, čeprav se uporablja ta termin tudi za slovarje, v katerih je izvedeno jezikovno obračanje (npr. nemško-slovenskega v slovensko-nemškega); tako so poimenovani slovarji Alasie da Sommaripa, Ožbalta Gutsmana, Krajnsko besediše pisano sem tako poimenovala tudi sama. Ker ta izraz terminološko ne ustreza, ker je že zaseden za v SSKJ ${ }^{2}$ omenjeni retrogradni ali odzadnji slovar, bi bila dobrodošla tudi navedba zveze obratni slovar, ki se uporablja za to vrsto.

Spremembe v prvem pomenu sestavka slovar $\mathrm{v} \mathrm{SSKJ}^{2}$ glede na $\mathrm{SSKJ}^{1}$ so označene s pre- in podčrtavo:

\begin{abstract}
slovár -ja m (á)
1. knjiga, v kateri so besede razvrščene po abecedi in pojasnjene: slovar ima sto tisoč besed; izdati, sestavljati slovar; prevajati s slovarji; obsežen slovar / na koncu knjige je slovar seznam s tako razvrščenimi in pojasnjenimi besedami / enojezični, enozvezkovni, narečni, pravopisni, tehniški slovar; elektronski slovar slovar v elektronski izdaji; enozvezkovni slovar slovar, ki navadno po združitvi predhodnih v daljšem časovnem obdobju izdanih posameznih delov, izide v enem zvezku, eni knjigi; slovensko-nemški slovar; slovar tujk / knjiž. poučni slovar enciklopedija, leksikon / Slovar slovenskega knjižnega jezika; lingv. jezikosl. avtorski slovar ki vsebuje besede določenega avtorja; etimološki, frekvenčni, informativno-normativni slovar; obrnjeni slovar odzadnji slovar; odzadnji slovar urejen po absolutnem abecednem redu od zadnjega konca besede; razlagalni slovar; slikovni slovar $v$ katerem so pojmi ponazorjeni s slikami in poimenovani; zgodovinski slovar
\end{abstract}

Med posodobitve spada tudi podomačenje terminološkega označevalnika (lingv. nadomesti jezikosl.) ter odprava stilnega označevalnika $\mathrm{v}$ drugem pomenu 'besedni zaklad', ki v nevtralni rabi ni več stilno označen z ekspr., ostaja pa v frazeološkem delu: $\mathrm{SSKJ}^{1}$ : 2. nav. ed., ekspr. besedni zaklad: imeti bogat slovar / njen slovar ni bil ravno izbran $\bullet e k s p r$. besede nemogoče ni v njegovem slovarju odločen je narediti tudi navidez nemogoče stvari; ekspr. če to povemo v ekonomskem slovarju tako, kot pravijo ekonomisti.

Težav z razlago iztočnice slovar pa ni imel Pleteršnik, ker je v Slovensko-nemškem slovarju (1894-1895) izražena s prevodnimi ustreznicami. Vendarle najdemo tudi v oz. na njem sled heterogene uredniške »politike«, saj je slovaropisno svetoval domačo iztočnico besednjak, v naslovu pa izbral že takrat dodobra uveljavljeni rusizem slovar, ki smo ga vendarle obdržali (čeprav izraza 
slovo v pomenu 'beseda' ne ohranjamo in jo je že Jarnik v svojem poskusu etimološkega slovarja 1. 1832 označil za zastarelega), obe iztočnici sta označeni kot novoknjižni:

slovár, -rja, $m$. = besednjak, das Wörterbuch, Mur., Cig., Jan., nk.; - rus.; besẹdnják, $m$. das Wörterbuch, Jan., $n k$.

Ob tem se moramo vprašati, katero zbrano besedje lahko opredelimo z izrazom slovar, in kdaj gre le za določen seznam besed, ki ne ustreza slovaropisnim načelom, zato ga navadno označuje izraz besedišče. Kaj je in kaj ni slovar, se je razvnela debata tudi ob poimenovanju konkordančnega nabora slovenskega starejšega knjižnega besedja, Jezikovnih virov starejše slovenščine (http://nl.ijs.si/imp/), ki vsebuje kar štiri besedne zbirke različnih velikosti od S (zastarele besede), M (starinske besedne oblike), L (vse besede) do XL (vse besedne pojavnice) in so poimenovane z izrazom besedišče, ki je bil sicer Pohlinu sopomenka za slovar, tako še Pleteršniku, ne pa več SSKJ-ju, kjer je besedišče opredeljeno kot 'besedni zaklad'. Zakaj to ni slovar, nam zaradi zgornje razlage ni treba pojasnjevati: ker ni knjiga. A verjetno so kritiki merili na drugi del razlage: ker besedje ni (ustrezno) pojasnjeno. Načeloma to ne drži: če si pogledamo samo vzorčni primer, je sodobna ustreznica zapisana, celo s podatkom, od kod je vzeta (iz konteksta, ki je v ponazarjalnem gradivu), torej ustreza razlagi v SSKJ-ju:

čimž samostalnik, občno_ime, moški (zastarela beseda) \goo300k, IMP $\nearrow$ SSKJ, Pleteršnik obresti; kontekst

- čimža

Zlata Vas (1848): $\quad$ posebej vpraša: »Komu si dolžán? Koliko? in koliko obresti ali čimža daješ od sto? Na kom si se zadolžil in ali

Zlata Vas (1848): $\quad$ popraševati. Nekteri že tri, štiri ali pet lét ni obresti (čimža) odrajtal. Zató se je moglo narprej skerbéti. Marsikteri je mogel

Seveda kaj hitro najdemo primere, kjer manjka npr. sopomenka ali razlaga iz

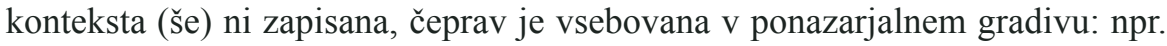

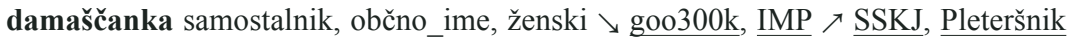

- damaščanka

Novice gospodarskih, $\quad$ Nemško. Iz Damaska je tista sliva, ki se dan današnji obertnijs... (1857): „ »damaščanka« zove. Nekdaj so iz jutrovih dežel le suhe češplje v

Ne da bi posebej iskali, le zgolj radovednost ob nepoznanem leksemu, in mimogrede naletimo na napake, ki jih je »zagrešila« računalniška obdelava in je sama ne more odpraviti, saj je še vedno potreben pregled in urejanje izkušenih slovaropiscev. V naslednjem primeru ne ustreza prečrkovanje iztočnice, ker sta znaka za $\int$ in $\mathrm{f}$ zelo podobna. Tudi razlaga ni natančna niti ni navedena sopomenka iz sobesedila, ki bi jo lahko osvetlila: 
siršpan samostalnik, občno_ime, moški(zastarela beseda) $\searrow$ goo300k, IMP

vprežna žival; kontekst

- siršpan

- Iirlhpan

Kmetijske in rokodelske novice (1843): fe je poftaral, jim ki kadaj, ako ne bolehva, zhveter (firfhpan) previdva. — - Kaj je pa bolji krajnfko, »ofhtir« ali »birt?« - -

četver samostalnik, občno_ime, moški (zastarela beseda) \goo300k, IMP $\nearrow \underline{\text { SSKJ }}$ Pleteršnik vprežna žival; Pleteršnik

- četver

- zhveter

Kmetijske in rokodelske novice (1843): ki fe je poftaral, jim ki kadaj, ako ne bolehva, zhveter (firhpan) previdva. — — Kaj je pa bolji krajnfko, »ofhtir« ali »birt

Pri sopomenki je iztočnica enako razložena, vir je tokrat Pleteršnikov slovar, ker izposojenk iz nemščine po večini nima, je bil zgoraj razbran pomen iz sobesedila, zaradi neprepoznavnosti začetne črke in nepovezanosti z nemškim izrazom pri Pleteršniku, ki bi izraz lahko pojasnil, pa je razlagalna besedna zveza vprežna žival nenatančna, saj gre za vprego štirih živali, četverovprego, kar sam izraz čveter tudi pojasnjuje. V Pleteršnikovem slovarju je to geslo zapisano takole:

1. četvệr, f. das Viergespann, Jarn., Cig., Jan.; v četver se voziti, vierspännig fahren, Str.; v čétver, Lašče- Erj. (Torb.).

Če pogledamo še k sosednjim geslom, takoj opazimo napačno uvrstitev, saj besedotvorno četver $(<\check{c}$ veter $>$ ) ne sodi pod četveren, temveč pod četver, saj nima priponskega obrazila $-e n$.

četveren pridevnik, splošni, nedoločeno \goo300k, IMP $\nearrow$ SSKJ, Pleteršnik

- četverne

- čveterne

Kmetijske in rokodelske novice (1844):

- četvernega

- čveterega

$\begin{array}{ll}\text { Novice gospodarskih. } & \text { mašina že pervo leto splača, ako se cena žita imenovanega } \\ \text { obertnijs... (1856): } & \text { ćveterega, eno k drugemu, le po } 4 \text { fl. vagán rajta. Res }\end{array}$

Kako pa je $v$ jezikovnih virih starejše slovenščine prikazana iztočnica slovar? Najdemo jo $\mathrm{v}$ seznamih vseh vrst besedišča, razen pri zastarelih besedah (S: »malo besedišče vsebuje samo zastarele besede, pri čemer je vsaki pripisana sodobna ustreznica oz. razlaga«), kjer se pojavi besedotvorna varianta slovnik, za razlago pa služi Pleteršnikov slovar, kjer je zapisan njen češki izvor: 
slovnik samostalnik, občno_ime, ženski (zastarela beseda) \goo300k, IMP $\nearrow \underline{\text { SSKJ }}$ Pleteršnik slovar; Pleteršnik

- slovnik

Kmetijske in
rokodelske novice
(1846):
Kmetijske in
rokodelske novice
(1846):
Kmetijske in
rokodelske novice
(1846):
to ob kratkem povém, da nam ni treba niti za slovnik, še menje za slovnico tujíne, ako le svojíno zvestó poiščemo

tukaj ves vnet povém, da mi Slovenci imámo gledé na slovnik in slovico obílo blagá - le samo po deržélicah raztergani smo

in pregibo našega razrečja izkušal, in sem takó svoj Slovensko-narodni slovnik in primerjeno slovnico po etymologičkih in analogičkih pravilih spisal, da

— slovnik samostalnik, občno_ime, moški (zastarela beseda) \goo300k, IMP $\nearrow \underline{\text { SSKJ}}$, Pleteršnik slovar; Pleteršnik slovnika
Kmetijske in rokodelske novice
pa 260 milijonov kristjanov na svetu. Proglas zastran noviga (1846): slovenskiga slovnika in slovnice. (Konec.) Lehkič kakega izmed mojih ljubih rojákov pri

Med starinskimi besednimi oblikami (M: »srednje veliko besedišče vsebuje gesla, ki imajo vsaj eno besedno obliko, ki so jo nekoč pisali drugače, kot jo pišemo danes«), pa najdemo poleg zastarelega izraza slovnik, ki nastopa tu z drugimi primeri v različnih sklonih, tudi izraz slovar, čeprav gre le za zapis v bohoričici in z naglasnim znamenjem, ki ni starinski.

slovar samostalnik, občno_ime, moški \goo300k, IMP \SSKJ, Pleteršnik

- slovar

- flovar

Kmetijske in rokodelske novice (1844): koriftnifhi delo, ki fi ga je naloshil, je bilo: »Némfhko-flovenfko-latinfki flovár, kakorfhniga fo s nami vred domazhi Şlavijani she sdavnej pogrefhovali

Kmetijske in rokodelske novice (1844): jih je okoli 30 tavshent v flovenfkim jesiku sa imenovan flovár fkupej fpravil, ktérga je miflil v léti 1813 natifniti

- slovarja

- slovnika

Novice gospodarskih, obertnijs... (1855): presvitlega našega knezoškofa za pokušnjo pridjan obljubljeni listek nemško - slovenskega slovnika, ki bo, na podlagi Vodnikovega rokopisa stoterno pomnožen, prišel na

- slovarjem

- slovnikom

Novice gospodarskih, obertnijs... (1855): ti ponudi; Le jemat' od nje ne zamudi!« S predragim slovnikom vred, se mi zdi, Da Vodnikov duh se zdaj v

- slovarju

- slovniku 
Novice kmetijskih, rokodelnih ... (1851): to je: po vsih svojih življejih v slovnici in v slovniku, pak — zavoljo bratovske nesloge raztresen med narečji. Na primér: Tako Novice gospodarskih, obertnijs... (1856): plenus, n spremenjen v r). V rumunskem jeziku, po Bobbovem slovniku »Dictionariu rumunese lateinesk si ungarese«, se te imena tako glasijo

Tudi med L (»veliko besedišče vsebuje vsa gesla razen nezanimivih, kot so imena, cifre, tiskarski škrati itd.«) in XL (»celotno besedišče vsebuje čisto vsa gesla besednih pojavnic iz ročno označenega korpusa«) se ponovijo že navedene oblike.

Iz zgornjih primerov lahko ugotovimo, da je Pleteršnikov slovar nepogrešljiv in priročno dosegljiv za razlago zgodovinskega besedja in za določanje pomena. Samo CTRL in klik na povezavo nas pripelje do želene iztočnice. In še vedno ostaja nenadomestljiv tudi za preučevanje sodobnega besedja (primerjalno ali razvojno), pomena narečnih in starejših izrazov, besedotvornih, pomenskih izraznih možnosti ipd. Po drugi strani pa je razvidno, da tudi sodobna oblika konkordančnega slovarja ne more nastati zgolj z računalniško obdelavo, brez budnega očesa strokovnjakov slovenistov.

Škoda, da ob posodabljanju SSKJ-ja še ni bil upoštevan tudi »glas ljudstva« prek spletne strani. Poleg dodanih vrst slovarjev v slovarskem sestavku za iztočnico slovar si zasluži svoje mesto med njimi poleg Slovarja slovenskega knjižnega jezika tudi Pleteršnikov slovar kot primer ne za lastnika, ampak častitljivega urednika, ki je sicer le uspešno odbral in uredil zbrane besedne zbirke številnih avtorjev, a mu je za vedno dal pečat sestavljavca.

Irena Orel

Filozofska fakulteta, Univerza $v$ Ljubljani

\section{FRAZEMI IN PREGOVORI V SLOVENSKIH SPLOŠNIH IN SPECIALIZIRANIH SLOVARJIH (S POUDARKOM NA SLOVARJIH 19. STOLETJA)}

Frazeološke in pregovorne enote, ki so v slovenistiki obravnavane v okviru frazeologije ( $\mathrm{v}$ ožjem in širšem pomenu), so slovenski slovaropisci že v preteklosti vključevali v splošne dvo- in enojezične slovarje ter jih v določeni meri prepoznavali kot specifično gradivo, na katerega je $\mathrm{v}$ slovarju treba posebej opozoriti. Tovrstne enote so lahko s posebno leksikografsko pozornostjo obravnavane tudi samostojno, ${ }^{1}$ in sicer v specializiranih (frazeoloških) slovarjih ali frazeološko-paremioloških podatkovnih bazah, ki nastajajo zlasti v zadnjih letih.

V 19. stoletju sta po obsegu vključenega frazeološko-paremiološkega gradiva in tudi po slovaropisni metodologiji njegovega predstavljanja izstopala splošna

\footnotetext{
${ }^{1}$ Govorimo o frazeografiji oz. paremiografiji.
} 
dvojezična slovarja, ki sta nastajala v sklopu tedanjega slovenskega slovaropisnega projekta: (1) Deutcsh-slovenisches Wörterbuch Mateja Cigaleta (1860) in (2) Slovensko-nemški slovar Maksa Pleteršnika (1894/95). Frazeološke in pregovorne enote so bile $\mathrm{v}$ obeh slovarjih inventarizirane kot del celotnega slovenskega leksikalnega gradiva ter na podoben način vključene v slovarsko makro- in mikrostrukturo (prim. Ulčnik 2014). Tako pri Cigaletu kot pri Pleteršniku se pojavlja možnost njihovega pojasnjevanja z drugojezičnim sistemskim ali prevodnim ustreznikom, npr. Auge, das /.../ vier Augen sehen besser als zwei, več oči več vidi; hvála, f. I... / svoja hvala se po blatu valja, = eigenes Lob stinkt, Npreg.; Cirkuliren, v. n. /.../ das Geld cirkulirt, dnar gre, hodi, teče (po deželi, od roke do roke), najdemo pa tudi nekaj pomensko nepojasnjenih slovenskih enot. To pomeni, da v Cigaletovem slovarju manjka enota v izhodiščnem ( $\mathrm{tj}$. nemškem) jeziku oz. da v Pleteršnikovem slovarju ob slovenski enoti ni nemške ustreznice: Früh, adj. /.../ cfr. Spr. kdor zgodej vstaja, temu kruha ostaja; óča, $m$. = oče; /.../ kar dobiš po oči, varuj po dnevi in po noči, Npreg.- Notr. Iz tega je razvidno, da sta oba slovaropisca izhajala (tudi) iz slovenske frazeološko-paremiološke dediščine, ki sta jo želela v čim večji meri zajeti v slovarju. Pri Cigaletu se pojavlja tudi hkratno navajanje drugojezičnih sistemskih in prevodnih ustreznikov, opazno pa je celo navajanje sistemskih ustreznikov v drugih slovanskih jezikih - tako se je zapolnila vrzel, ki bi nastala zaradi odsotnosti slovenskega sistemskega ustreznika ob nemški izhodiščni enoti (npr. Erst, adv. /.../ vorher (erst) soll man denken, dann sprechen, popred, vpervo, prej misli in potle govori, serb. Sprichw. izpeci pa reci). Posebna odlika obeh slovarjev so dodatna pojasnila v slovenščini, ki so zlasti v Pleteršnikovem slovarju že močno približana sodobnim pomensko-pragmatičnim pojasnilom, npr. péta, $f$. l.../ kdor nima v glavi, mora imeti v petah (reče se, kadar kdo mora nazaj iti po kako pozabljeno reč). Slovarja nakazujeta tudi variantnost in sopomenskost slovenskih enot, zlasti slednje pa močno izstopa v Cigaletovem slovarju, npr. A /.../ wer a sagt, muß auch $b$ sagen, kdor stopi $z$ eno nogo, mora stopiti tudi $z$ drugo; beseda besedo želi; kdor je začel, naj dokonča. Cigaletovo variantno navajanje enot je nemalokrat zajel tudi Pleteršnikov slovar, npr. jẹ́lọ, n. /.../ brez dela ni jela, Cig., C., Vrt.; kdor ne dela, je brez jela, Cig.; kjer je delo, tam je jelo, Arbeit bringt Brot, Cig. O predvidljivem in zanesljivem mestu, na katerem najdemo frazeološke in pregovorne enote, pri slovarjih 19. stoletja še ne moremo govoriti, kljub temu pa je v Pleteršnikovem slovarju slovarski prostor bolj ekonomično izkoriščen, saj se frazemi in pregovori v večji meri pojavljajo zgolj na enem mestu. Opazno je tudi, da sta oba slovaropisca po svojem jezikovnem občutku sicer zaznavala strukturno-semantično posebnost teh enot, zaradi česar sta jih v posameznih primerih označila s posebnimi označevalniki (npr. Cigale s Spr., Sprichw., Pleteršnik s preg., Npreg.), vendar pa te oznake niso zanesljiv pokazatelj vsega frazeološko-paremiološkega gradiva (prim. Ulčnik 2014).

Frazeologija in paremiologija je vključena tudi v dva splošna enojezična slovarja - v Glonarjev Slovar slovenskega jezika (1936) in v Slovar slovenskega knjižnega jezika (1970-1991). Ker pa je bilo v času nastajanja obeh slovarjev frazeološko in pregovorno gradivo $\mathrm{v}$ jezikoslovju še precej neraziskano in 
teoretično neobdelano, so pri njegovem prikazu opazne določene pomanjkljivosti, npr. zapis v neslovarski obliki (četudi je slovarska oblika izpričana že v slovarjih 19. stoletja), na kar je stroka že opozorila (prim. Kržišnik 2013: 17-18). V SSKJ so frazemi in pregovori načeloma vključeni v poseben razdelek, imenovan frazeološko gnezdo (npr. sìt síta -o prid. /... • /.../ ekspr. narediti tako, da bo volk sit in koza cela da bo prav za obe strani), vendar se veliko gradiva pojavlja tudi izven tega razdelka (npr. béli -a -o sam. /.../ ekspr. dobil boš črno na belem napisano izjavo, potrdilo; nikóli prisl. /.../ bolje pozno kot nikoli tudi z zamudo opravljeno dejanje je vredno priznanja).

Slovensko frazeološko gradivo je lahko prikazano tudi v specializiranih frazeoloških slovarjih, med katerimi je treba omeniti večjezični slovar Josipa Pavlice iz leta 1960 in prvi slovenski enojezični frazeološki slovar Janeza Kebra - Slovar slovenskih frazemov (2011). V slednjem je v okviru posebnega razdelka (in analogno po primerljivih evropskih slovarjih) opozorjeno tudi na medjezikovna razmerja. Avtor v Uvodu opozarja, da so v širšem smislu v frazeologijo vključeni tudi »frazemi s stavčno ali večstavčno sestavo, kot so reki, pregovori in krilatice« (Keber 2011: 9), vendar pa meni, da te enote ne spadajo v frazeološki slovar, temveč v posebne slovarje. Kljub temu jih nekaj najdemo tudi v našem najizčrpnejšem frazeološkem slovarju, saj je, kot pravi avtor, »tako narekovala njihova aktualna frazeološka raba« (Keber 2011: 9), npr. povezanost med frazemi in pregovori (»Frazem velika riba je verjetno nastal po pregovoru Velike ribe malo žro«; Keber 2011: 806).

Vse navedeno predstavlja pomembna izhodišča za razmislek o novih možnostih leksikografske predstavitve tovrstnih enot. Med letoma 2010 in 2013 se je v okviru nacionalnega projekta Frazeologija nemškega jezika, Nemško-slovenski medkulturni in kontrastivni vidiki že začel pripravljati frazeološko-paremiološki nemško-slovenski spletni portal. ${ }^{2}$ Pri tem so se ob slovenskem gradivu pojavila številna redakcijska vprašanja, vezana na: (1) obravnavo variantnosti, (2) oblikovanje ustreznih pomensko-pragmatičnih določil, (3) načela izbora prioritetnega in slovarsko primernega gradiva (ob odsotnosti slovenskega frazeološkega minimuma) $)^{3}$ ipd. (prim. Jesenšek, Ulčnik 2014).

Dosedanje slovarske predstavitve frazemov in pregovorov so tudi pomembno gradivo diahronih raziskav, saj omogočajo vpogled v njihovo spremenljivost na formalno-skladenjski in semantično-pragmatični ravni. Nekatere enote tako izkazujejo že več kot stoletno prisotnost v nespremenjeni ali delno spremenjeni obliki (s trebuham za kruham > iti s trebuhom za kruhom; sreča je opotočna $>$ Sreča je opoteča), kažejo se postopki njihovega ustaljevanja (npr. unter Vier Augen - med nama, mej dvema > na štiri oči) in morebitnega nadomeščanja

${ }^{2}$ Doslej sta že bila izdelana dva modela za prikaz frazeološko-paremioloških vsebin, in sicer dvojezično didaktično zasnovano okolje Ephras ter petjezična zbirka pregovorov Sprichwort Plattform.

${ }^{3}$ Slovenski paremiološki minimum je bil objavljen konec leta 2013 v reviji Slavia Centralis (prim. Ďurčo, Meterc 2013). 
s sopomenkami (npr. denar je gospodar > Denar je sveta vladar). Opazujemo lahko celo posledice, ki jih puščajo kulturne in družbene spremembe, zaradi katerih so v današnjem času v ospredju enote, ki v preteklosti še niso izstopale ali pa jih nismo poznali (npr. pranje denarja; Najprej delo, potem zabava; Za lepoto je treba potrpeti). Frazemi in pregovori se torej razvijajo in odzivajo na (zunaj)jezikovne dejavnike, nekateri se umikajo iz rabe, drugi se prenavljajo ali nastajajo na novo oz. se pojavljajo s prevzemanjem iz tujejezičnega okolja, vseskozi pa ostajajo pomembno in učinkovito večfunkcijsko besedilno sredstvo, ki bi moralo biti tudi slovaropisno ustrezno obravnavano.

\section{REFERENCE}

Peter ĎURČO, Matej METERC, 2013: Empirične paremiološke raziskave tipov ekvivalentnosti in suprasemantičnih razlik v slovenščini in slovaščini. Slavia Centralis VI/2, 20-36. Vida JESENŠEK, Natalija ULČNIK, 2014: Spletni frazeološko-paremiološki portal: redakcijska vprašanja ob slovenskem jezikovnem gradivu. Več glav več ve. Frazeologija in paremiologija v slovarju in vsakdanji rabi. Maribor. 276-292.

Janez KEBER, 2011: Slovar slovenskih frazemov. Ljubljana.

Erika KRŽIŠNIK, 2013: Moderna frazeološka veda v slovenistiki. Frazeološka simfonija: Sodobni pogledi na frazeologijo. Ljubljana. 15-26.

Natalija ULČNIK, 2014: Slovensko paremiološko in frazeološko gradivo v temeljnih dvojezičnih slovarjih 19. stoletja - v Cigaletovem nemško-slovenskem (1860) in Pleteršnikovem slovensko-nemškem slovarju (1894/1895). Frazeologija nemškega jezika z vidikov kontrastivnega in uporabnega jezikoslovja. Maribor. 282-319.

Natalija Ulčnik

Filozofska fakulteta, Univerza v Mariboru

\section{MOJE IZKUŠNJE S SLOVAROPISJEM}

Slovaropisje je bilo vsa univerzitetna leta moj vsakdanji kruh. Občutil sem ga kot zahtevno, a na moč osrečujoče delo. Pri tem so bile zaželene neopazne krščanske kreposti kot vztrajnost, doslednost, predanost, prepričanje in veliko potrpljenja, ki mu pravimo tudi božja mast. Pa še natančnost in ljubezen do podrobnosti nista smeli manjkati. Jasno je, da bi vsi radi imeli slovar takoj na mizi, nihče pa se ne vpraša, koliko časa je zanj potrebno, piše Gutsman v predgovoru k svojemu nemško-slovenskemu slovarju leta 1789.

Že kot študent sem začutil čar in besedno moč naših koroških govorov. Starejšim vaščanom so prihajale besede na dan, da je kar vrelo. Govorili so, kot bi rožice sadil. Odločil sem se, da zapolnim belo liso na narečnem zemljevidu, ki se je pokrivala z mejami kapelske občine in jo je Ramovš imenoval obirsko narečje. Poglobil sem se v domače govore, jih primerjal s sosednjimi in zbiral 
gradivo celih 15 let. Nazadnje sem ugotovil, da živemu jeziku ne prideš do dna. Mislim sem, da poznam vse odtenke posameznih besed, a sem se, ko sem prišel domov, vedno spet poučil o nečem drugem. Nazadnje je beseda baba imela 7 pomenov, pók pa osem. A verjetno še ni bilo vse. Slovarček je z vso alpsko poetiko in materialno kulturo nato izšel v sklopu knjige Der Obir-Dialekt in Kärnten (1990) - prvem poskusu celostnega opisa kakšnega slovenskega narečja na osnovi govorne situacije. In še dobro, da je knjiga izšla, kajti informanti so pomrli, v 100 letih pa bi se morda podvomilo, ali so v teh krajih nekoč sploh živeli Slovenci ali ne, kajti kakšnih piramid ali templov niso zapustili, grable in vile pa so nezadosten dokaz za obstoj bogate karavanške ustne tradicije.

Drugi, zelo resen poskus slovaropisja je potekal v 80-ih letih, ko sva se s pravnikom dr. P. Apovnikom lotila slovarja Nemško slovenskega in Slovensko nemškega pravnega in ekonomskega jezika za vsakdanje potrebe koroških Slovencev. Šlo je za pravno terminologijo, ki ne le poimenuje, pač pa tudi determinira in kodificira. Pri tem sta pomembna jasnost in enoznačnost izrazov. Pojmoval sem ga kot prispevek k transparentnosti abstraktne pravne nemščine, ki je celo Nemcem težko razumljiva, po drugi strani pa kot prispevek k boljšemu dostopu do prava in večji pravičnosti, ki je odvisna tudi od tega, ali državljani razumejo zakone in se lahko nanje zanesejo ali ne. Prvi del z ekscerpirano avstrijsko zakonodajo je izšel leta 1989, ko je Slovenija postajala demokratična država, drugi del s slovensko terminologijo pa leta 1996, ko ni bilo več tajnice in sem gradivo $\mathrm{v}$ računalnik moral vnesti sam. Zdaj bi bilo treba slovarja posodobiti, a ni ne osebe ne sredstev.

Tretji slovar, s katerim sem imel nato opravka dobri dve leti in je izšel leta 1999, je bil obrnjeni prvi praktični nemško-slovenski slovar, Gutsmanov Deutsch windisches Wörterbuch iz leta francoske revolucije. Zaradi velikega števila slovenskih ustreznic ga je bilo smiselno obrniti v slovensko-nemško smer. Pri tem se je izkazalo, da niso bile vse besede vzete iz živega jezika, pač pa, da jih je veliko bolj ali manj uspešno skoval po nemškem kopitu sam. Hlačeserjalec (nem. Hosenscheißer), se gotovo nikoli ni uporabljal, ker so na voljo kurkej, kekej, mevža, mevžej in še kaj. Prabeseda ol (vu) za pivo je sicer živa v Rožu še danes, ne ve pa se, ali je bilo dejansko med ljudstvom tudi vseh enajst izpeljank, ki jih navaja: olov, olovn, olovnija, olovnica, olovnik, olovnišče, olovnjak, olovanje, olovar, olovarski in olovati. Zaradi tega Gutsmana tudi nismo mogli ekscerpirati kot gradivo za Tezaver slovenskega ljudskega jezika na Koroškem.

Tezaver pa je bil četrti leksikografski projekt - eden od petih ciljev dolgoročnega projekta o invenatarizaciji slovenskega ljudskega jezika na Koroškem, ki sta ga vložila prof. Stanislav Hafner in Erik Prunč. Po petintridesetih letih je delo zdaj obtičalo pri 7. knjigi (črka $m l$-, ne pa še pri $m r$-, kot $m r t e v$ ). Kaže, da bo dragocena konkordanca po tem osnutku ostala iz več razlogov torso, kot jih je v slavistiki najmanj deset. Pravzaprav pa trideset let ni veliko, če pomislimo, da se je inventariziranje bavarskih narečij v Avstriji začelo leta 1913, 
delo s švicarskim idiotikonom pa celo leta 1806 in bo predvidoma leta 2022 zaključeno s 17 . knjigo.

Sistematizacija, semantizacija, leksikalizacija, geografska dodelitev slovničnih primerov, transkripcija 500 posebnih znakov zahtevajo nastavitev najmanj dveh glavnopoklicnih delavcev z dobrim poznavanje terena, ne pa, da delo sloni na plečeh nekoga, ki ga mora opravljati ob siceršnjih poklicnih dolžnostih na univerzi. Ura ni več pet pred polnočjo, marveč le še dve minuti pred tem, da se oglasi v zvoniku zvon.

Ob pogledu na svojo skromno slovaropisno dejavnost vam hočem le čestitati, da obstaja v Sloveniji Inštitut za slovenski jezik Frana Ramovša ZRC SAZU, kjer se strokovnjaki lahko izključno ukvarjajo s sestavljanjem slovarjev in kjer je nakopičeno toliko leksikografskega znanja kot nikjer drugod v Sloveniji.

Imel sem priložnost, da sem konec 70-ih let, ko sem študiral pri prof. Toporišiču v Ljubljani, spremljal nastajanje SSKJ. Na akademiji so delale same ženske, ki so postavile na glavo moje prepričanje o tem, da je slovaropisje od Grimma do Pleteršnika izključno moška zadeva. Tedaj sem dobil velik rešpekt pred slovenskimi ženskami! In ko je prvi del izšel, sem ga večkrat prebiral kot kakšen roman, članek za člankom in se čudil kaj vse gesla vsebujejo. Bil je podoben užitek, kot bi prebiral Grimma ali Wahriga.

Ker slišim, da se pripravlja nov slovar slovenskega knjižnega jezika, je zame, ki gledam stvari od zunaj, več kot jasno, da novi slovar ne more priti od drugod kot pa iz uveljavljenega in preizkušenega ZRC-ja, ki je ob sodelovanju drugih strokovnjakov gotovo edini poklican, da glede na tradicijo, avtoriteto in kvalifikacijo direktorja inštituta ter glede na ogromno znanje sodelaveev izda tako zahtevno delo, ki bo v ponos vsem pišočim in zavednim Slovencem.

\section{Ludvik Karničar}

Inštitut za slavistiko, Univerza Karla in Franca v Gradcu

\section{VPRAŠANJA O GRADIVU ZA SLOVAR}

Ker naj bo po načrtu prispevek kratek, problematika je pa zelo obsežna in ni enaka za vse tipe slovarjev, bom govoril samo o gradivu, kakršnega bi ob slovaroslovnem delu, s katerim sem se začel ukvarjati že ob diplomi in po njej, potreboval, in o tistem in takem, ki ga kolikor toliko dobro poznam in sem ga uporabljal do zdaj ob tem delu.

Gradivo za slovar je vse, kar je zbrano po določenih kriterijih za kako slovarsko delo in kar je slovaropiscu na voljo pri izdelavi slovarja. Možnosti za gradivo so različne. Popolno gradivo bi bilo, ko bi obsegalo vsa besedila izbranega obdobja in področja. Večinoma so doseženi bolj ali manj popolni približki. V novejšem času pa sploh, ker je besedil zelo veliko. Najlaže dostopna so pisana besedila. Zajemanje samo govorjenih besedil je teže, ker je vezano 
na posebno tehnologijo in možnosti dostopa do njih. Največkrat govorimo o gradivo za slovarje knjižnega jezika.

Za različne naloge $\mathrm{v}$ slovaroslovju je potrebno za tiste naloge primerno gradivo. To pomeni, da imamo različna gradiva za različne slovarje. Zelo mnogostranska gradiva so primerna tudi za več slovarjev. Osnovno načelo je, da mora gradivo prinašati tiste podatke, ki jih določene naloge potrebujejo. Podatki pa morajo biti z vseh področij jezika enakomerno zastopani. Nekateri podatki so potrebni pri vseh slovaropisnih in slovaroslovnih nalogah.

Slovarji potrebujejo podatke o besedah. Vsi podatki o življenju in vlogah besed se uresničujejo v besedilih. Vsa besedila bi nudila vse podatke. V sodobnem knjižnem jeziku je težko zbrati vse gradivo. Zato se je treba zadovoljiti z bolj ali manj primernim izborom. Najzanesljivejši so podatki, ki jih prinašajo bližnje okolice uporabljene besede. Ker je bilo včasih težko dolgo sobesedilo v celoti prepisati, so se zbiralci pogosto zatekali k skrajšanim posplošitvam o pomenu in drugih podatkih. Pri tem je bil lahko kak podatek izgubljen ali zanemarjen. Danes imamo že veliko tehnologij, s katerimi postanejo tudi daljši konteksti laže dosegljivi in dostopni. Gradiva so toliko obsežna, da je možna večstranska analiza. Omogočajo tudi dostop do podatkov, ki jih zbiralec gradiva še ni opazil ali pa mu niso bili pomembni, popolno gradivo jih pa vsebuje.

Nastane vprašanje o kakovosti gradiva. Gradivo, ki obsegalo samo podatek, katera beseda obstaja v jeziku in v kakšnem pomenu, je za razvito slovaropisje preskromno. Za temeljne slovarje potrebujemo o besedi čim več podatkov, poleg glasoslovnih, oblikoslovnih in besednovrstnih podatkov še zlasti podatke o pomenu in stilu besede. Ti podatki so skriti v besedilih in se kažejo na skladenjski ravnini v najširšem pomenu tega izraza. Ker imajo skoraj vse besede več pomenov, je vloga besed $\mathrm{v}$ besedilu tudi zelo pomembno teoretično vprašanje. Zato morajo biti slovaropisci podkovani z znanjem, kako se posamezni pomeni kažejo v besedilih. Pri pomenski analizi iščejo take lastnosti. Če so teoretično podkovani jih lahko opazijo, drugače ni nujno, da jih vidijo.

Ker sem se razmeroma zgodaj začel ukvarjati z besedjem knjižnega jezika, zlasti umetnostnega, sem raziskoval zlasti pomene besed in slogovne vrednosti posameznega pomena. Za te naloge je potrebno pridobiti veliko ali čim več okoliščin, v katerih posamezna beseda nastopa. Te okoliščine sem poimenoval besedne zveze, čeprav sem se zavedal, da včasih vse besede iz takih zvez ne stoje skupaj, ampak samo spadajo skupaj. Struktura zveze je lahko prekinjena s kakim dodatkom.

Besedne zveze so postale zelo pomembne, ko sem ugotovil, da se pomeni združujejo v pomenske skupine. Izraz pomenska skupina sem uporabil za pomene, ki imajo podobno strukturo tipičnih besednih zvez in jih dojemamo, da so po pomenu sorodni. Pri pomenskih razvojih besed se srečujemo s prehodom besede iz ene pomenske skupine $\mathrm{v}$ drugo.

Značilno pri takem pomenskem prehodu je, da beseda $\mathrm{v}$ novem pomenu prevzame tipične zveze nove pomenske skupine. To spoznanje sem štel za zelo pomembno, ker postavlja razmejevanje, povezovanje in dokazovanje pomenov na objektivno raven. 
Besedne zveze v najširšem pomenu imajo za določevanje pomenov izredno pomembno vlogo. Zato sem pri delu vedno iskal čim več gradiva. Pri delu za SSKJ sem v sicer zelo kvalitetnem listkovnem gradivu večkrat čutil pomanjkanje podatkov. Rabil bi še več gradiva. Po spominu in iz svoje zbirke izpisov iz besedil sem ugotavljal, da imajo nekatere besede v jeziku poleg pomenov, ki so izkazani v kartoteki, še kak pomen. Tudi sam sem se prizadeval, da bi odkrili nove tehnologije za zbiranje gradiva, zlasti pri izpisovanju novejših besedil, ki so bila že za objavo napisana s pomočjo računalnika.

Včasih, ko še ni bilo strojev za zbiranje gradiva, so bile možnosti omejene. Dolgo in uspešno zgodovino imajo izpisi na listke, ker so zelo gibljivi in jih lahko uvrščamo po različnih kriterijih. Gradivo na listkih, ki so urejeni zlasti po abecednem redu iztočnic, so bili in so še za slovarsko delo zelo primerni. Za zgodovinski slovar knjižnega jezika 16. stoletja oziroma slovenskih protestantskih piscev 16. stoletja smo pri popolnem izpisu vseh besed in imen iz vseh besedil, pisanih v slovenščini, prilagodili izpise tako, da smo preslikano besedilo iz originala razdelili na dele za listke velikosti a 6 in na začetku in koncu izpisanega dela dodali po dve vrstici, tako da je vsaka izpisana beseda imela še nujno sobesedilo. Izdelali smo matrice in jih opremili z lokacijo. Matrice smo razmnožili, kolikor je bilo potrebno, da je dobila vsaka beseda za vsako pojavitev svoj listek. S tem smo dosegli natančnost originala in zmanjšali možnost pomot pri prepisovanju, predvsem pa zelo skrajšali čas izpisovanje posameznih besed. Ta postopek je zelo primeren za popolni izpis. Pri nekaterih pomenih, zlasti pri nekaterih besednih vrstah, je potrebno daljše sobesedilo, kot ga lahko spravimo na listek ali v eno vrsto v konkordanci. V takih primerih je treba pri analizi seči v original. Pri slovenskih protestantih je veliko takih mest.

Za gradivo se v novejšem času močno uporablja izraz korpus, zlasti za gradivo ki je zbrano in urejeno z računalniško tehnologijo. Za vsa gradiva veljajo načela, kako naj bodo gradiva zbrana urejena in opremljena z lokacijami. Važno je to, da so odvisna od nalog slovarjev, za katere so namenjena in da so opremljena z zanesljivimi podatki. Morda bi bilo dobro opozoriti na pojave, do katerih lahko pride, če je delo opravljeno površno. Če je v izpisu pisna posebnost ali napaka, je treba označiti, ali je iz izvornega besedila. Podatek o lokaciji mora biti tolikokrat prekontroliran, da je malo možnosti za napake.

Določanje, kakšno gradivo je potrebno za kak slovar, je zelo pomembno vprašanje. V zgodovini slovenskega knjižnega jezika so se z njim zelo veliko ukvarjali. Vsi pomembnejši slovarji omenjajo odločitve v uvodih. Čeprav so ti popisi za današnji čas, ko je skoraj vsako besedilo zelo razvlečeno, zelo ekonomični, so nujni za razumevanje slovarjev in nudijo veliko podatkov tudi za teorijo o gradivih za slovarje.

Zelo pomembno je vprašanje, katera besedila so z gradivom zajeta in v kakšni obliki. Kakor hitro gre za izbrana besedila, mora biti izbor zelo utemeljen. Načela izpisa morajo biti natančno določena. Če kaka kategorija izrazja v izpisu ni zajeta, mora biti utemeljeno in popisano, kako je uporaba tiste kategorije predstavljena. 
Pri tako raznovrstnih in številnih besedilih, kot jih poznamo danes, je pri vsakem gradivu za vsako slovarsko delo potrebno povedati, kaj je v gradivu zajeto in česa ni. V vsakem obdobju postavljajo besedila pred zbiralcem gradiva posebna vprašanja, ki jih mora zbiralec raziskati in jih za gradivo na primeren način prikazati. V načelih mora vsaj omeniti, kako je $v$ gradivu taka posebnost rešena. Sedaj je na primer aktualno vprašanje, kako zajeti tujejezične vstavke v besedilih, zlasti, če niso pojasnjeni. Danes je veliko takih uporab, ki jih velikokrat povprečni bralec ali poslušalec ne razume natančno. Tako je že besedilo nekako invalidno dostopno.

Ko uporabljam gradiva, kolikor so prosto dostopna, kot gradivo za pomensko in stilno analizo posameznih besed, se večkrat vprašam, ali je izpis dovolj uravnotežen, da bi lahko bil kolikor toliko objektiven. Močno je zastopano časopisje. Tu je internacionalizacija jezika zelo močna. Zelo pa pogrešam podatke iz boljšega leposlovja in boljše publicistike. Premalo je spremljanja boljšega prevajanja. Veliko pa je izpisov iz obrobnih žanrov. Korpusi so velikokrat preveč enostranski. Zato je kljub visokim številkam kaka lastnost jezika slabo upoštevana. Nič ni hudega, če se tega dejstva vsi uporabniki zavedajo, slabo je to, če kdo svoj korpus kljub nepopolnosti proglaša za zadostnega.

Za slovarsko gradivo je zanimivo vse, kar kaže resnico o jeziku. Če se kak trend pretirano izpisuje, drugo pa zanemarja, je že slabost. Tista dela, ki kažejo samostojen razvoj jezika, pa naj gre za leposlovno, strokovno, publicistično, novinarsko, humoristično, prevodno besedilo, mora priti bolj do izraza v gradivih kot zgolj stopicanje na šablonskih poteh. Pri razvijanju našega knjižnega jezika moramo nekako upoštevati tradicijo razvoja našega knjižnega jezika od protestantskih piscev naprej, drugače bomo zašli v razne težave. Jezikovni ustvarjalci, ki odkrivajo razvojne možnosti slovenščine za nove naloge, morajo dobiti primerno mesto tudi $\mathrm{v}$ novih gradivih za nove slovarje. $\mathrm{V}$ razpravah o gradivu pogrešam več razmišljanja in zagovarjanja pri odločitvah in iskanjih najboljših možnosti.

France Novak Inštitut za slovenski jezik Frana Ramovša, ZRC SAZU, Ljubljana

\section{O VLOGI SLOVENŠČINE KOT JEZIKU ZNANOSTI}

(Prispevek k diskusiji)

O slovenščini kot jeziku znanosti in univerzitetnega izobraževanja je lani in letos potekala zelo intenzivna diskusija. Na univerzah so se namreč okrepile težnje, da je treba čim več programov izvajati v angleščini, češ da je to jezik znanosti, s katerim bomo na naše univerze privabili več tujih študentov 
kot doslej. V zvezi s kriteriji, kdaj in kako uvajati angleščino, pa je zavladala popolna zmeda. Ta zmeda z nejasnimi cilji je bila toliko bolj žalostna, ker se je v nji izkazalo, da se za pavšalno rabo angleščine na vseh nivojih zavzemajo tudi slovenski rektorji, in to brez posvetovanja s slovenistično stroko. Kadar pa se je stroka - in celo jezikoslovna znanost! - v zvezi s tem oglasila, je bila označevana kot »preveč prestrašena« in »domačijska«.

$\mathrm{V}$ javnosti je potekala široka in burna razprava o novi podobi Zakona o visokem šolstvu, $v$ katerem je v 12. členu opredeljena tudi raba slovenščine na slovenskih univerzah. Ta člen po mnenju mnogih premalo natančno določa, da je lahko jezik poučevanja na slovenskih univerzah predvsem slovenski. Obenem smo bili soočeni z mnenjem slovenske Rektorske konference, ki je želela pod krinko »internacionalizacije« uzakoniti rabo tujih jezikov pri izvajanju visokošolskih študijskih programov. Seveda si pri tem ni prizadevala, da bi pri nas predavanja potekala v nemščini, italijanščini, francoščini, ruščini, poljščini ..., temveč je šlo za samoumevno favorizacijo angleščine v razmerju do drugih jezikov. Na to je opozorilo Slavistično društvo Slovenije, na to so opozarjali jezikoslovci, npr. Marko Jesenšek na Seminarju slovenskega jezika, literature in kulture (Ljubljana: FF, 2014, str.: 42-49), pa tudi ugledni člani SAZU na Posvetu o slovenščini v visokem šolstvu in znanosti (6. 3. 2013), o tem so potekale razprave (npr. na FF UM). Opozarjali smo, da je slovenski jezik ustavna kategorija in da mora tudi Zakon o visokem šolstvu to dosledno spoštovati. Zapisali smo, da odločitev glede rabe slovenščine ne sme biti prepuščena posameznim univerzam, rektorjem ali rektorskim konferencam, statutom itd. Tudi sama sem zapisala, da je slovenščina naša materinščina, obenem pa da je to naš državni jezik, jezik nacionalne identitete, morala pa bi biti tudi jezik nacionalnega ponosa in samozavesti.

Slovenščina seveda ni le naš pogovorni jezik, temveč tudi razviti jezik znanosti in umetnosti, za katerega je trajalo stoletja, da se je lahko polno uveljavil. Danes, v sodobnosti, imamo torej razviti umetnost in znanost $v$ slovenščini, ki pa ju moramo prevajati $v$ druge jezike, ne pa je začeti ustvarjati $v$ tujih jezikih. Univerza z vsemi svojimi študijskimi programi tako na dodiplomskem kakor na podiplomskem študiju pa seveda ni le porabnica slovenskega znanstvenega jezika, temveč tudi njegova nadvse pomembna soustvarjalka. Preprosto povedano: Če bomo slovenščino nehali uporabljati kot jezik znanosti, se ta jezik tudi ne bo več razvijal in bo počasi bo celo zakrnel; postal bo ohlapen in brez žive izrazne, kreativne moči.

$\mathrm{O}$ tem, kar sem zapisala, pričajo številni dogodki, ki sem jim bila v zadnjem času priča. Na osrednjem slovenskem zboru slovenskih raziskovalcev in znanstvenikov v Ljubljani (v hotelu Mons, 2013), kjer je bila predstavljena nova raziskovalna strategija Evrope, so nastopili trije visoki predstavniki Evropske zveze. Vsi so predavali v angleščini, vsi tudi brez prevajanja $\mathrm{v}$ slovenščino. Za njimi je nastopil tudi mladi slovenski znanstvenik, ki je zaposlen v Bruslju (mimogrede: je sin slovenskega pisatelja, ves svoj dodiplomski študij pa je opravil na slovenski, to je ljubljanski univerzi). V svojem uvodnem nagovoru se je številni slovenski publiki - sredi Ljubljane! - opravičil, da bo predaval 
v slovenščini, ker da tega jezika ni več vajen, saj v Bruslju govori le »evroangleščino«. Jezik znanosti, je še povedal slovenski znanstvenik, je zdaj namreč le še angleščina. To pa je le en primer. Prepričana sem, da se vsakdo od vas spominja vsaj kakega simpozija na domači univerzi ali v širšem slovenskem okolju, ki se je od začetka do konca odvijal le v angleščini, brez prevajanja, ki bi bilo vsaj pri izvlečkih referatov nujno in spodobno. Številni naši znanstveniki so na to naraščajoče in samoumevno vsiljevanje angleščine opozarjali, pisali članke, dokazovali, da je to škodljivo (gl npr. zbornik Sonje Starc z Univerze na Primorskem), a zdi se, da doslej zaman. Sama sem si še pred nedavnim dopisovala $\mathrm{z}$ rektorjem mariborske univerze, ki je v svojem pozdravnem nagovoru na mednarodni poletni šoli v Mariboru udeležence, ki so prišli k nam tudi zato, da se naučijo slovenščine, pozdravil le v angleščini, niti besede pa ni spregovoril po slovensko. Prav tako sem opazila, da ima svoj predstavitveni življenjepis na spletni strani univerze, ki je slovenska javna univerza, objavljen le $\mathrm{v}$ angleščini. Po mojem bi ga moral imeti objavljenega tudi v slovenščini, in to najprej v slovenščini ter šele nato $v$ angleščini, saj je slovenščina naš državni jezik. S tem pa bi upošteval tudi dejstvo, da so vsi jeziki EZ enakopravni ter da na tak način izražamo zlasti spoštovanje do materinščine. Toda kadarkoli sem zoper tako pretirano, klečeplazno rabo angleščine, protestirala, so mi odvrnili, da slovenščina pač »še ni tako ogrožena« ter da tako delajo tudi drugje po svetu ...

Ker pa sem po tem drugem svetu nekaj malega potovala tudi sama, saj sem živela in tudi predavala v tujini, vem, da temu ni tako. Če hoče študent študirati na nemški univerzi, mora najprej opraviti izpit iz nemškega jezika. Ali pa predložiti mednarodno veljavno potrdilo o znanju nemškega jezika (npr. Goethejevega inštituta); za doktorski študij se ponekod zahteva tudi znanje jezika na nivoju C1 ali C2. Prav tako je npr. v Španiji. Prav tako je v Avstriji; če navedem le nekaj držav iz naše ne tako oddaljene tujine. In res je tudi naslednje: Če želi habilitirani profesor konkurirati za profesorsko mesto na tuji univerzi npr. $\mathrm{v}$ Avstriji ali Nemčiji, mora odlično obvladati nemško. Angleščina (ali kak drug jezik, npr. ruščina ali francoščina) je pri tem šele na drugem mestu. Znanje državnega jezika je povsod na prvem mestu - in predstavlja bistveni pogoj za zasedbo delovnega mesta.

Kaj bi se lahko iz tega naučili? Vsaj to, da od slovenskega profesorja na slovenski javni univerzi pričakujemo odlično znanje slovenščine. - Toda ne, pri nas slišimo iz ust profesorjev zlasti na tehniških in naravoslovnih smereh, da se slovensko ne znajo več izražati, ker predavajo in tudi pišejo znanstvene članke le še $\mathrm{v}$ angleščini! Pri tem jih zelo podpira tudi razvpito slovensko vrednotenje znanstvenih rezultatov pri ARRS, ki objave $\mathrm{v}$ tujih znanstvenih revijah, največkrat $v$ angleščini, ocenjuje $\mathrm{z}$ večjim številom točk kakor objave $\mathrm{v}$ domačih znanstvenih revijah in pri domačih znanstvenih založbah.

Pa naj še kdo reče, da slovenščina »še ni tako ogrožena«. In kdaj potemtakem bo dovolj ogrožena, da se bomo tega končno v polni meri zavedli?! Ko bomo slovensko lahko govorili le še doma, na dvorišču in ob domačem ognjišču, v univerzitetnih predavalnicah ter političnih salonih pa bomo med seboj občevali le še angleško? 
S svojimi zapisi sem doslej opozarjala na to, da takega poniževanja slovenščine, kakršnemu smo priča $\mathrm{v}$ najnovejšem času, $\mathrm{v}$ vsej zgodovini še nismo doživeli, zlasti ker si slovenščine še nikoli nismo ukinjali kar sami. Tragično pri tem pa je seveda tudi to, da si za ukinjanje znanstvene slovenščine ne prizadevajo ljudje z obrobja, neki neuki posamezniki z ulice ali s ceste, temveč da je to nasilna in neprikrita želja nekaterih, ki naj bi veljali za vrhove slovenske inteligence. Če bodo njihove težnje zmagale, bomo postali tujci v hiši domačinov, sem zapisala v Delu, 17. 12. 2013.

Toda če bi ti univerzitetniki poznali kulturno zgodovino Slovencev, bi vedeli, da ravnajo hudo narobe. Slovenski pisatelj Florjan Lipuš je v svojem zadnjem delu Poizvedovanje za imenom zapisal, da je bila slovenščina v zgodovini jezik, zaradi katerega so nas zmerjali in tepli. Zapisal je, da je slovenščina praznično oblačilo naroda. In če se v to praznično oblačilo ne bodo več ogrinjali tisti, opozarja pisatelj, ki so bistri, globljih spoznanj in miselnih krivulj sposobni, bo naš jezik izumrl.

Takih misli pa so tudi številni znanstveniki in umetniki, člani Slovenske akademije znanosti. Naj navedem le nekaj njihovih misli z omenjenega posveta v marcu 2013, objavljene v zborniku Razprave/ Dissertationes XXII, SAZU Ljubljana, 2014:

Neumnost, piše pisatelj in Prešernov nagrajenec za literaturo Saša Vuga, sama po sebi še ni nevarna; nevarna je, kadar jo ustoličimo. In še: »Vsak, ki nas je hotel uničiti, je najprvo uničeval našo besedo. /.../ Dobro so vedeli: Iztrgati je treba besedo - zakaj s tem iztrgaš srce.« (Razprave SAZU XXII, 2014: 37)

Marko Snoj je zapisal, da jezik seveda ni samo komunikacijsko sredstvo, temveč da je to ogledalo mišljenja. Opozoril je na to, da je tisti, ki se izraža $\mathrm{v}$ tujem jeziku, avtomatično v podrejenem položaju v primerjavi s tistimi, ki so naravni govorci. Če pa o strokovnih rečeh ne bomo več govorili in pisali slovensko, slovenščine ne bomo mogli več uporabljati niti na poljudni ravni. Taka raba vodi v razkroj jezika. Nadalje je zapisal: »Dalje se moramo vprašati, kakšna bi bila angleščina, ki bi se začela množično uporabljati na Slovenskem. Izkušnje narodov, ki so tak korak storili v preteklosti, nas učijo, da bi bil to jezik $\mathrm{z}$ angleškim besedjem, poenostavljeno slovnico in močnim substratnim vplivom slovenščine. Bila bi torej lingva franka, ki bi ob zamiranju slovenščine prehajala v kreolski jezik. Bila bi to, kar je neuradno edini uradni jezik Evropske unije: slaba angleščina.« (Razprave SAZU XXII, 2014: 14)

O jeziku je razmišljal akademik Peter Gosar, fizik in matematik: »Materni jezik je za večino ljudi osnova za nemoten razvoj osebnosti in lastnega miselnega sveta. Redki lahko v tujem jeziku izrazijo svoja najgloblja občutja, fantazije, doživetja in predstave.«

In še: »Zapis doktorskih del v slovenskem jeziku ni izguba časa. Ne predstavljam si, da bi nekdo, ki ne zna napisati lepega in logično zgrajenega teksta v slovenščini, napisal ustrezen spodoben tekst v drugem jeziku.« (Razprave SAZU XXII, 2014: 19)

Akademik Matjaž Kmecl je v svojem razmišljanju opozoril, da je šele po drugi svetovni vojni na Slovenskem nastala kompletna univerza, malo kasneje pa 
razvejano visoko šolstvo različnih specialnih področij: »Ne glede na delovanje različnih zveznih služb, predvsem vojske, v neslovenskem jeziku, se je zdelo, da je jezikovno vprašanje rešeno $v$ smislu slovenščine kot aksioma v Sloveniji. Ni treba posebej poudarjati, vsaj mislim tako, da je kolektivna (samo)zavest o tem aksiomu sčasoma dosegla stopnjo ene temeljnih motivacij za državno osamosvajanje.« (Razprave SAZU XXII, 2014: 23)

In dalje: »Jezikovna etika je pač dandanes tudi sestavina civilizacije - parafraziramo po De Gaullu: jezik Evrope je jezik jezikov; različni jeziki prispevajo različna razmišljanja in z njimi rešitve; torej so rastišče ustvarjalnosti. Še posebej, ker ni »velikih« in »malih« jezikov, to je takih, ki jih govorijo velike ali pa majhne množice. Jezik je ne glede na število »uporabnikov« suveren v celoti, kar pomeni, da je zmožen vsakršne izrazitve, vseh filozofemov in (tehničnih) novotarij; ali pač je invaliden, manjvreden in nebogljen, ter ga, preprosto, ni. Vse drugo so, še enkrat več, izgovori in prišepetavanja komodnosti.« (Razprave SAZU XXII, 2014: 24)

Podobno so o slovenščini razmišljali Marko Jesenšek (na SSKJLIK, Ljubljana FF, 2014), v zborniku Slovenske akademije znanosti pa Niko Grafenauer, Tadej Bajd, Alojz Kralj, Jože Maček, Janez Orešnik, Boris Paternu, Miha Tišler, Jože Trontelj, Kajetan Gantar, Mitja Zupančič in Janko Kos.

Silvija Borovnik

Filozofska fakulteta, Univerza v Mariboru

\section{Slovesnost ob 20-LetniCi Pleteršnikovega MUZEJA V PIŠECAH 2. OKTOBRA 2014}

(Gradivo za okroglo mizo - Posvet o slovenščini v visokem šolstvu in znanosti, dvorana SAZU, 6. 3. 2013)

Stališča sodelujočih na posvetu je mogoče strniti v naslednjih nekaj poudarkov in tako premostiti neusklajenost med politiko razvoja na področju znanosti in univerzitetnega razvoja in univerzitetnega izobraževanja na prvi ter jezikovno politiko na drugi strani:

- slovenščina ima na slovenskih univerzah mesto dominantnega jezika;

- tujim študentom se ponudi čim več študijskega gradiva v angleščini (prevodi skript, učbenikov), konzultacije z njimi potekajo v angleščini;

- določiti je treba obvezni del izvajanja visokošolskih programov (različno za naravoslovje, medicino, tehniko, družboslovje in humanistiko) v slovenskem jeziku in ne v celoti prepustiti univerzam;

- na ravni doktorskega študija se univerzam prepusti avtonomna jezikovna politika; pravica doktoranda je, da svojo disertacijo napiše v slovenščini. 
Misli akademika Kajetana Gantarja na Posvetu o slovenščini z naslovom: Kakšno siromašenje: »Predlogi, ki bi sčasoma pripeljali do absolutne anglizacije našega univerzitetnega študija, pomenijo veliko zmoto in zablodo ... Naše članstvo v SAZU in naša državljanska zavest narekujeta največjo možno skrb za ohranjanje, uveljavljanje, negovanje in bogatenje slovenščine na vseh področjih. Slovenija je edina država na svetu, v kateri je slovenščina uradni jezik, edina država, ki je nastajala in se rodila ob slovenskem jeziku. Če bi nam kaka ustanova zaupala, da napišemo zgodovino slovenske države, bi lahko začeli tako kot evangelij: »V začetku slovenske države je bila slovenska beseda. Že četrt tisočletja pred Brižinskimi spomeniki, najstarejšim slovenskim pismenim spomenikom, v latinskih besedilih najdemo zapise slovenskih besed, in med prvimi, kar morda ni slučaj, besedo župan (jopanus), ki kaže na državotvornost naših prednikov ...« Zato lahko v slovenski besedi bolj kot v orožju in bolj kot v političnih strukturah vidimo edino in najmočnejše poroštvo za obstoj in razcvet slovenske države: dokler bo zvenela slovenska beseda, toliko časa bo živela tudi slovenska država. Če pa bi slovenska beseda kdaj utihnila, bi tudi slovenska država in z njo tudi Slovenska akademija znanosti in umetnosti kot njena najvišja znanstvena ustanova izgubila svoj smisel obstoja in izdihnila«. (Razprave - Dissertationes XXII, SAZU, Ljubljana, 2014)

Zinka Zorko

SAZU, Ljubljana

\section{KOZJANSKO - BIZELJSKO NAREČJE - GLASOSLOVJE PIŠEČKEGA GOVORA \\ (Gradivo za okroglo mizo)}

Po Tinetu Logarju in Jakobu Riglerju spada kozjansko-bizeljsko narečje v štajersko narečno skupino. V to skupino spadajo srednještajersko, zgornjesavinjsko, srednjesavinjsko, južnopohorsko narečje in kozjaški govor.

Fran Ramovš je v svojih Dialektih (1935) večino govorov od Konjiške gore in Boča do Lisce, Bohorja, Tisovca, Svetih gora štel k osrednji štajerščini, le na jugu ob Sotli naj bi bilo bizeljsko-obsoteljsko narečje z vplivom dolenjščine. Tine Logar (1996) v svoji razpravi Karakteristike štajerskih govorov južno od Konjiške gore in Boča to narečje poimenoval kozjansko-bizeljsko. Melodično in ritmično ga prištevamo k štajerski narečni skupini. Južno od črte Kalobje - Sodna vas ob Sotli in do črte Lisca - Bohor - Pilštanj - Golobinjek slišimo govorico, ki jo razvojno označujejo naslednje posebnosti: odraz za jat je lahko v posameznih govorih: e:î́, a:í, široki e, ozki ẹ (Pilštanj); nosni ę in etimološki e sta se razvila v široki e, etimološki o in samoglasniški r sta se poenoglasila iz o:u v u, za dolgi u pa se tod govori ü. Kratki in umično naglašeni samoglasniki so se podaljšali, nenaglašeni samoglasniki se lahko reducirajo. 
Govori Orešja, Bizeljskega in Pišec so si v glasoslovnem in oblikoslovnem razvoju blizu, druži jih tudi skupna leksika. Izgubili so tonemsko nasprotje, besedna intonacija je le padajoča, kratki naglašeni samoglasniki so se podaljšali.

Za samoglasniški sestav pišečkega govora so značilni dolgi naglašeni samoglasniki: í, ú, ú, ẹ, ọ, à, á, á, âr.

Dolgi í je nastal iz stalno dolgega i, akutiranega i in iz kratkih akcentiranih i: líst, píšem, svíja, zíma, zít; lípa, ríba, tíči, žíla; míš, nít, tíč. (V nekaterih besedah se je razvil v dolgi široki ầ - năč, sä̀t.)

Dolgi ü je odraz za stalno dolgi, staroakutirani in kratki naglašeni u: klüčenca, lǘč, lǘpim; krüha, küpa, čútiti, obüit; krüh, küp. (Izjemoma se izgovarja dvoglasnik üe v edinem besednem zlogu: fküep.)

Dolgi ú zastopa stalno dolgi etimološki o, novoakutirani o, stalno dolgi samoglasniški ł̀̀: búk, gnúj, múč, núč; núsim, prúsno, vúla; čún, vúk, žúna; dúgi, púna, vúna; dúk, púh, pún. (Redko zastopa nosni Q: múšs, túča.)

Dolgi ozki ẹ je odraz za stalno dolgi jat, akutirani jat, za kratki in umično naglašeni jat, za vse naglašene nosne ę in za etimološki e: besẹda, lẹp, lẹs, lẹta, mlẹ́ko, smẹ́h, svẹcča, zvẹ́zda; brẹ́za, cẹssta, lệto, nevẹ́sta, strẹha; dẹt, sẹm; lẹpo, sẹno, tẹ́lo, tẹ́sto; pẹst, plẹ̌šem, zẹ́be me, mẹso; imẹna, lệt, pẹc , nẹsu, rẹ́ku, zẹle, žẹnih.

Dolgi ozki ọ́ zastopa stalno dolgi nosni o, akutirani in umično naglašeni o, novoakutirani etimološki o v zadnjem zlogu in umično naglašeni o: obrọ́k, golộp, klộp, mọdër, pọ́t, dọga, gọ́ba, zọ́bi, dnọo, kọsš, krộp, kọ́za, ọ́sa.

Dolgi in zelo široki ajevski fonem (ä) je odraz za umično naglašeni e, kratki in umično naglašeni polglasnik, kratki in umično naglašeni i: čălu, nắsem, răkkla,

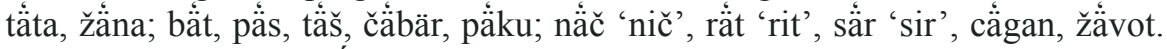

Dolgi labializirani ắ zastopa stalno dolgi a, akutirani a, kratki a, dolgi in novoakutirani polglasnik: ắpno, brắda, dvắ, glắva, kovắč, krắl; brắta, mắti; brắt, gắt, čăst, dắn, lắn, vắs; gắne, mắša, pắhne.

Dolgi samoglasniški ro se izgovarja ăr: kărt, smărt; čărna.

Samoglasniški ł̣ se je razvil v dolgi u: čún, kúnem, púnim, vúk, púna.

Nenaglašeni samoglasniki se ohranjajo, reducirajo ali pa onemevajo. Nenaglašeni i:písati, rẹ́zati, na mízi; cvílla, túlla, vílce, năsma, tắrpte; nastane tudi iz nenaglašenega polglasnika ali jata: pẹtik, vozíčik: nắklih, órih.

Nenaglašeni u je naslednik samoglasniškega ł in etimološkega o: jåbučik, kužúh, mučím, nusníca.

Nenaglašeni polglasnik se večinoma izgovarja kot ä: ärdečíca, ärjávi, pär 'pri'; lahko tudi onemi: člẹnk, mezínc; zvộnc.

Soglasniški sestav pišečkega govora je večinoma enak knjižnemu.

Posebni razvoji so naslednji: samoglasniški ł ima odraz u tako kot dolgi etimološki ó: čún, vúk, žúna, dúga, púna, vúna; samoglasniški r r se izgovarja s širokim ä pred r: pắrst, smắrt, tấrt.

Samoglasniški sklop -rl, -ru ima odraz ắru: dắru, cvắru, žăru, obắru.

Palatalni lj je izgubil palatalnost: krạ́l, stẹ́la, vúla, zămla.

Palatalni nj je večinoma izgubil mehčanost: jíva, kắmje, korẹje, lükja, ọgen. 
Zvočnik v se izgovarja kot v, ự, f: víno, vọ́da, vúna, člọ́uk, dấrf, fceẹri, vứho ( $\mathrm{v}$ je proteza).

Zvočnik j se govori tudi kot sekundarni fonem: grọ́jzdje, lọjpa, pújstela.

Sklop dl se lahko izgovarja kot -1-: jẹla, pála.

Sklop šč se razvil v š: gọ́ša, íšem, klẹšse, píše, na tấše.

Govor ne pozna preglasa o v e za c, j, č, ž, š: s strícom, bọ́jom, kováčom, nọ́žom.

Podoben glasoslovni razvoj je znan tudi na Bizeljskem in v Orešju. Drugi južni kozjansko-bizeljski govori se od teh razlikujejo zlasti v govoru Lesičnega, kjer so znani dvoglasniki: û́o, iẹ́, úọ, in v Kapelah, kjer se je dolgi jat razvil v zelo ozki ẹ́.

Zinka Zorko

SAZU, Ljubljana 